\title{
Concurrent changes in latecomer capability-building and learning: Firm-level evidence from the Thai biogas industry
}

Reinauer, Tobias; Hansen, Ulrich Elmer

Published in:

Journal of cleaner production

Link to article, DOI:

10.1016/j.jclepro.2021.125783

Publication date:

2021

Document Version

Peer reviewed version

Link back to DTU Orbit

Citation (APA):

Reinauer, T., \& Hansen, U. E. (2021). Concurrent changes in latecomer capability-building and learning: Firmlevel evidence from the Thai biogas industry. Journal of cleaner production, 290, [125783].

https://doi.org/10.1016/j.jclepro.2021.125783

\section{General rights}

Copyright and moral rights for the publications made accessible in the public portal are retained by the authors and/or other copyright owners and it is a condition of accessing publications that users recognise and abide by the legal requirements associated with these rights.

- Users may download and print one copy of any publication from the public portal for the purpose of private study or research.

- You may not further distribute the material or use it for any profit-making activity or commercial gain

- You may freely distribute the URL identifying the publication in the public portal 


\section{Journal Pre-proof}

Concurrent changes in latecomer capability-building and learning: firm-level evidence from the Thai biogas industry

Tobias Reinauer, Ulrich Elmer Hansen

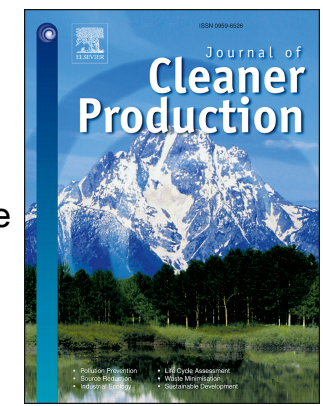

PII:

S0959-6526(21)00003-2

DOI: https://doi.org/10.1016/j.jclepro.2021.125783

Reference: JCLP 125783

To appear in: Journal of Cleaner Production

Received Date: 4 August 2020

Revised Date: 18 November 2020

Accepted Date: 30 December 2020

Please cite this article as: Reinauer T, Hansen UE, Concurrent changes in latecomer capability-building and learning: firm-level evidence from the Thai biogas industry Journal of Cleaner Production, https:// doi.org/10.1016/j.jclepro.2021.125783.

This is a PDF file of an article that has undergone enhancements after acceptance, such as the addition of a cover page and metadata, and formatting for readability, but it is not yet the definitive version of record. This version will undergo additional copyediting, typesetting and review before it is published in its final form, but we are providing this version to give early visibility of the article. Please note that, during the production process, errors may be discovered which could affect the content, and all legal disclaimers that apply to the journal pertain.

() 2021 Elsevier Ltd. All rights reserved. 
Tobias Reinauer: conceptualisation, methodology, investigation, resources, data curation, writing - original draft, writing - review and editing, project administration, funding acquisition; Ulrich Elmer Hansen: conceptualisation, methodology, validation, writing original draft, writing - review and editing, supervision 


\title{
Concurrent changes in latecomer capability-building and learning: firm-level evidence from the Thai biogas industry
}

\section{Authors}

Tobias Reinauer a, present address: $\mathrm{b}^{*}$

Ulrich Elmer Hansen $b$

a: Institute for Sustainable Resources, University College London, Central House, 14 Upper Woburn Place, WC1H 0NN, London, United Kingdom

b: UNEP-DTU Partnership, Technical University of Denmark, Marmorvej 51, 2100 Copenhagen, Denmark

*: corresponding author, email: tobre@dtu.dk, phone: +45 45335296

\section{Word count}

Body text excluding figures and data tables: 8828

\begin{abstract}
The localisation of clean-tech industries allows developing countries to align their economic growth aspirations with efforts to reduce the associated environmental impacts. A key issue in this regard is the development of technological capabilities at local firms in these countries. Although much research has been conducted on this topic, we currently have only limited understanding of how the learning mechanisms that these so-called latecomer firms engage in change as they deepen their capability stocks. In the present paper, we offer insights into this issue by means of a comparative analysis of nine technology-supplying firms in the Thai industry for industrial-scale biogas systems over a period of about twenty years. Our results suggest that there are indeed shifts in the relative importance of different types of learning mechanisms as firms deepen their capabilities. The paper finds that such shifts tend to follow a co-evolutionary pattern involving shifts within and across learning mechanisms that involve different sources of knowledge. Based on our analysis, we provide examples of how decision-makers can adopt targeted interventions for the support of cleantech firms and industries that are at particular levels of development.
\end{abstract}

\section{Keywords}

Technological capabilities; latecomer firms; biogas; Thailand 


\section{Introduction}

The development of technological capabilities among so-called latecomer firms has been identified as a key driver for industry localisation, competitiveness, job creation, and economic development in the countries of the Global South (Dahlman et al., 1987; Katz, 1984; Lall, 1992). Over the past decades, a large body of literature has emerged focusing on how latecomers develop their capability stocks (ibid.; Bell and Pavitt, 1995; Dutrénit et al., 2013; Romijn, 1999). This includes many studies on firms in clean-tech industries (Figueiredo, 2017; Hansen et al., 2020; Hansen and Ockwell, 2014; Kiamehr, 2017; Lema et al., 2018; Quitzow et al., 2017).

A central idea in this line of research is that firms accumulate capability stocks of varying levels of depth (Ariffin, 2010; Bell \& Pavitt, 1995; Figueiredo, 2003; Lall, 1992). A key determinant for the success of the firm in this regard are the learning mechanisms that it engages in, which include learning based on firm-internal activities and learning based on knowledge that lies beyond the firm's organisational boundaries (Bell and Figueiredo, 2012). Today, there is a substantial body of literature that provides empirical insights into how firms use different kinds of learning mechanisms to build their capability stocks (e.g., Dutrénit, 1998; Figueiredo, 2003; Hobday and Rush, 2007; Kiamehr, 2017; Kim, 1997; Scott-Kemmis and Chitravas, 2007).

Surprisingly, there is only little research focusing on how the nature of these learning mechanisms changes as firms transition towards successively higher levels of capabilities (Bell and Figueiredo, 2012: 69). Although the case-study literature provides scattered insights in this respect, few studies analyse this issue explicitly and systematically. The little existing literature on this subject focuses primarily on the sectoral level (Figueiredo et al., 2013; Hansen and Lema, 2019). Thus, there is scope to expand this line of investigation. Due to the heterogeneous, firm-specific nature of capability building and learning (Figueiredo, 2017; Lall, 1992), it appears to be particularly relevant to address this issue through analyses at the micro-level.

In the present paper, we examine concurrent changes in technological capability development and learning in the context of a multiple-case study of firms that offer green industrial goods in an emerging economy. Specifically, we present a comparative case study of nine firms in the Thai biogas industry, focusing on the period from 1991 to 2017. During this time, this industry experienced rapid growth and saw the rise of a number of successful, local firms. Today the Thai biogas industry is a regional leader and forms an important part of the Thai government's strategy for industry localisation, energy security, and low-carbon energy supply. Our study provides insights that can help policy makers decide on the design of targeted support measures to aid the localisation of clean-tech industries in the Global South.

Our analysis proceeds in three steps. First, we assess the capability development pathways of our nine case-study firms. This is based on a structured and transparent analysis of a large number of indicators providing insights into the firms' overall capability levels. Next, we study the kinds of learning activities that our case-study firms have engaged in. For this, we distinguish learning mechanisms by type (productivity-driven, innovation-driven, or humanresource-related) and by the origin of firms' newly acquired knowledge (firm-internal, external-domestic, or external-foreign). Finally, we combine our data on capabilities and learning mechanisms to study how the learning mechanisms that firms engage in change at different stages of the capability development process. Thus, we address the following research questions: What types of knowledge, skills, and experience have Thai biogas system 
suppliers acquired through internal and external learning? How have they acquired these? How do learning mechanisms change as latecomers build higher levels of technological capabilities?

The following section introduces the conceptual framework of the analysis. Section 3 provides contextual information about biogas systems and the Thai biogas sector. Section 4 describes the methods used for data collection and analysis, our sample of firms, and the operationalisation of key concepts. Sections 5 and 6 present and discuss the results. Section 7 reflects on the implications for policy and concludes the paper.

\section{Literature review and analytical framework}

\subsection{Latecomer technological capabilities}

We follow Van Dijk and Bell (2007: 151) in defining technological capabilities as the "skills, experience, knowledge, and organisational arrangements to acquire, use, adapt, and change existing technology and/or to create new technology." An important distinction here concerns the difference between non-creative, routine production activities and the capabilities required to manage and generate technological change (Bell and Pavitt, 1995). The former refer to the capabilities that firms need to operate production processes efficiently and to supply high-quality industrial goods. Capabilities to manage and generate technological change include a broad bundle of knowledge, skills, experience, and organisational systems required to engage in innovation. They enable firms to adopt and to use externally developed technology, to adapt and to improve this technology, and to develop new technology. Based on this basic distinction, various studies have developed detailed capability ladders, typically with reference to particular industries (Dantas and Bell, 2011; Dutrénit, 1998; Figueiredo, 2017; Hansen and Ockwell, 2014; Kiamehr et al., 2014; Tacla and Figueiredo, 2006; Tsekouras, 2006).

A key aspect of these studies is that latecomers typically start from low levels of capability stocks and then progress through various stages to higher levels, usually over the course of several years or even decades. A firm that moves up a "capability ladder" (see Table 1 for an illustration) becomes better at adopting and further developing products and processes of increasing novelty and complexity. While this does not necessarily imply that the firm becomes more competitive, there is compelling evidence indicating that innovativeness is related to competitiveness. For example, Peltoniemi (2011: 361) reviews 216 studies of industry life-cycles and finds that not a single one of these contradicts the notion that innovativeness provides competitive advantages. However, it should be noted that the present study focuses on how firms develop their technological capabilities, not on how capabilities are related to business performance (see Figure 1). 
Capability category $\quad$ Examples of activities falling under each capability level

\begin{tabular}{l|l|l}
\hline World-leading & $\begin{array}{l}\text { A large and diverse group of globally recognised research and development } \\
\text { (R\&D) experts and highly specialised engineers work on technology that is } \\
\text { likely to push the global technological frontier. This is based on applied and } \\
\text { basic research on radical, new-to-world product and process innovations. It } \\
\text { involves the application of state-of-the-art research tools and methods and } \\
\text { includes collaborations on technology development with other internationally } \\
\text { firms and research institutes. }\end{array}$ \\
\hline Advanced & $\begin{array}{l}\text { A varied group of specialised design and development engineers work on new- } \\
\text { to-country product and process innovations that are close to the international } \\
\text { technological frontier. The firm applies structured approaches to generate new } \\
\text { knowledge and collaborates closely with leading national and other } \\
\text { international organisations on technology development. }\end{array}$ \\
\hline Intermediate & $\begin{array}{l}\text { Specialised and well-trained engineers and technicians work on product and } \\
\text { process innovations that are new-to-firm or that involve substantial } \\
\text { modifications to existing technology. The firm effectively uses engineering } \\
\text { design tools to produce new knowledge. It collaborates with other domestic } \\
\text { firms and research institutes and interacts with other foreign-based } \\
\text { organisations to improve technology. }\end{array}$ \\
\hline Basic & $\begin{array}{l}\text { A small group of engineers and technicians work on minor improvements to } \\
\text { existing technology based on simple and sometimes outdated design and } \\
\text { engineering design tools. The firm mostly interacts with domestic } \\
\text { organisations to achieve minor adaptations in existing technology. }\end{array}$ \\
\hline
\end{tabular}

Table 1. Differentiation between levels of technological capabilities. Includes activities that indicate or "reveal" (Bell and Figueiredo, 2012: 50) what stage of development a firm has reached. Examples based on Amsden and Tschang (2003), Bell and Figueiredo (2012), Bell and Pavitt (1995), OECD (2005), Radosevic and Yoruk (2018). 


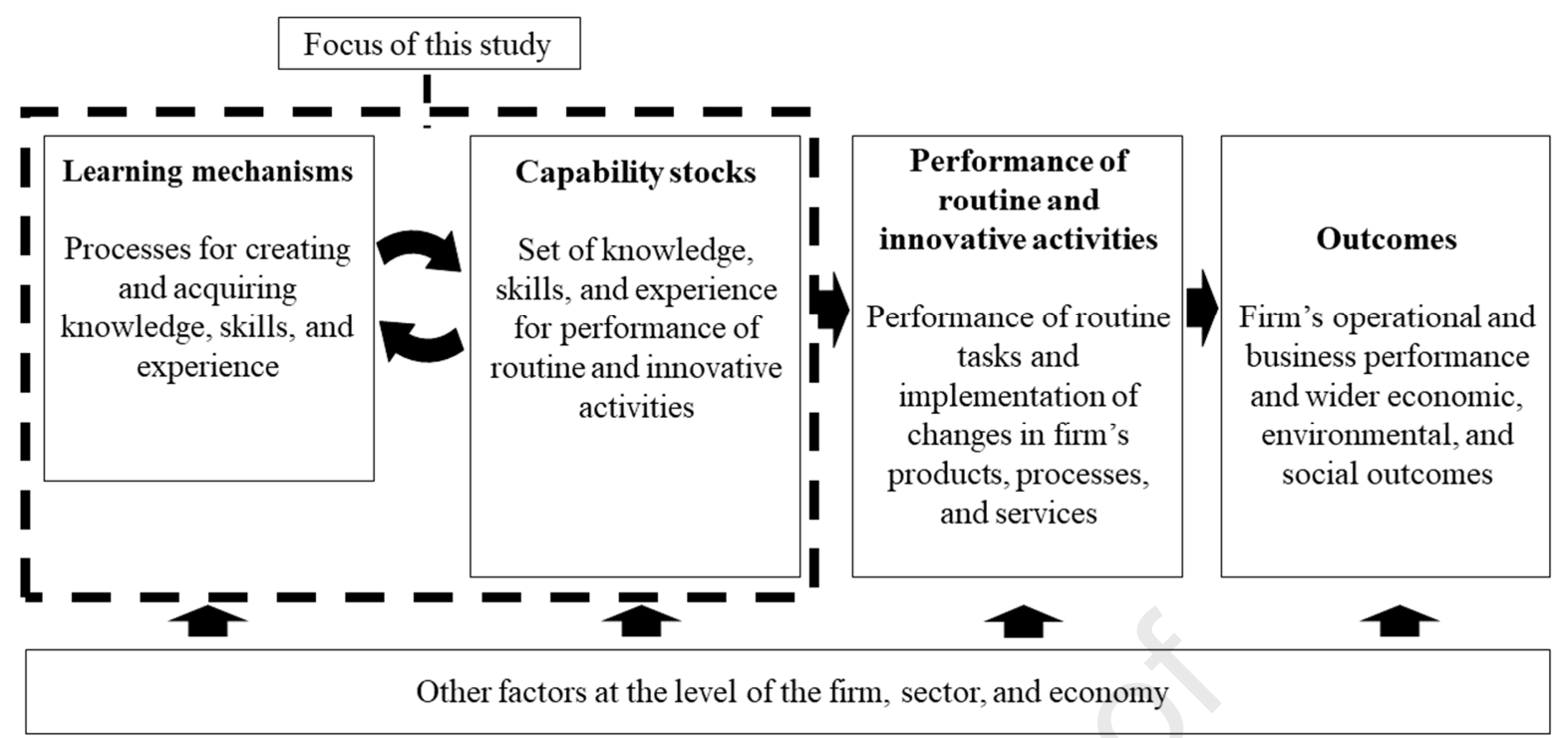

Figure 1. Analytical focus of this paper. Adapted from Bell and Figueiredo (2012).

\subsection{Technological learning}

We understand technological learning as long-term, cumulative, iterative, and deliberate processes that lead to improvements in the latecomer firm's capability stocks (Bell, 1984; Malerba, 1992). Multiple authors have developed lists of learning mechanisms that firms can engage in (ibid., Bell and Figueiredo, 2012; Figueiredo, 2003; Hansen and Ockwell, 2014; Kim, 1997). These typically distinguish between firm-internal learning mechanisms and mechanisms based on firm-external sources of knowledge. The latter are sometimes further distinguished based on whether they involve local/domestic or foreign sources of knowledge. Our goal here is not to repeat or extend these lists, but instead to draw on the existing literature to illustrate how we categorise learning mechanisms in our analysis. In doing so, we differentiate learning mechanisms along an additional dimension, which provides further conceptual clarity and offers a useful device to structure our complex, micro-level data. Specifically, we differentiate learning mechanisms based on whether they primarily take place as part of a firm's commercial projects, $R \& D$ efforts, or human-resource-related activities. Using these two dimensions (origin of knowledge and type of activity), we briefly outline key learning mechanisms in the remainder of this sub-section.

Firm-internal learning often takes place as part of a firm's commercial activities. This can involve relatively passive learning that occurs as part of routine activities, e.g., during day-today, hands-on problem-solving activities on the shop floor (e.g., Jonker et al., 2006). Similarly, firm-internal learning based on commercial activities can be based on efforts to optimise products and processes through more formally organised activities such as repair, maintenance, and troubleshooting. Firm-internal, R\&D-driven learning is based on learning by searching in specialised units of the firm, including dedicated task-force units, design and engineering departments, and research laboratories. Firm-internal learning can also be aimed at improving existing human resources, which takes place through internal knowledge sharing, e.g. via apprenticeship or classroom-type training sessions, the use of best practice databases, etc. (Nonaka, 1994).

Learning can also be based on firm-external sources of knowledge located either locally or nationally. With respect to learning based on commercial activities, this often involves horizontal linkages with other firms in the same industry, for example, through formal 
collaborations based on mutually complementary capabilities or, more informally, through imitation based on observation and reverse-engineering (Chen, 2009). Other learning opportunities for firms emerge during commercial activities through vertical linkages with users, input suppliers, and other partners. R\&D-driven learning in the local and domestic context, for example, in the form a demonstration project, typically involves collaborations with research institutes, often with support from government or donor agencies. Relevant human resource-related learning mechanisms include local or national training programmes and the recruitment of talent from local universities, competitor firms, or related industries.

Latecomer firms can also learn based on foreign sources of knowledge. With respect to learning in commercially focused activities, this can include a variety of channels for knowledge transfer, such as purchasing turnkey plants, equipment imports, spill-overs from inward foreign direct investment, international joint ventures, or subsidiary-parent relationships (Lema and Lema, 2012). Lately, R\&D-based linkages between partners in industrialised and emerging/developing economies have received some attention as vehicles of knowledge transfer (Ockwell et al., 2015). With respect to human resource-related learning, relevant learning mechanisms include foreign training programmes and the recruitment of foreign experts and intellectual returnees (e.g., Luo et al., 2013).

\subsection{Concurrent changes in capability building and learning}

Most empirical studies on latecomer capability building that account for both technological capabilities and learning mechanisms focus on the effects of the latter on the former (see Bell and Figueiredo, (2012) for a review). Only few discuss how a firm's stock of capabilities affects the kinds of learning mechanisms that it is able to engage in. This is somewhat surprising, as the idea of a two-way relationship between capabilities and learning mechanisms is closely related to the seminal works of Cohen and Levinthal (1990) and Kim (1998). Referring to learning based on firm-external sources, these authors argue that the firm's ability to absorb such knowledge depends on investments in firm-internal learning efforts. In turn, the firm's ability to make appropriate investments for this purpose largely depends on its pre-existing stock of knowledge. Hence, these authors suggest that, while engaging in learning allows the firm to build its capability stock, a deeper stock of capabilities also allows it to take advantage of more knowledge-intensive learning mechanisms.

Only a few studies have investigated the co-evolutionary nature of capability building and learning in a systematic manner. Most of our understanding of this relationship is based on evidence from single and small-N case studies that focus on other aspects of the latecomer capability-building process. Thus, they treat concurrent changes in capability stocks and learning mechanisms as a side issue (e.g., Dutrénit, 1998; Figueiredo, 2003; Hansen and Ockwell, 2014; Hobday and Rush, 2007; Kesidou and Romijn, 2008; Kim, 1997; Plechero, 2012; Scott-Kemmis and Chitravas, 2007).

To our knowledge, only two studies systematically investigate the relationship between capability stocks and learning mechanisms. This includes a study by Figueiredo et al. (2013), which focuses on the case of the natural resource-processing industry in Brazil. They find that firms combining internal and external learning mechanisms with high degrees of intensity and variety tend to achieve the highest levels of capabilities. However, they do not provide detailed information on specifically which combinations of learning mechanisms are most relevant. Also, their results are presented in a somewhat coarse manner, as they only compare learning mechanisms observed across two long periods of time (1950-1989 and 
1990-2010). Moreover, they do not differentiate firm-external learning mechanisms based on whether they involve domestic or foreign sources of knowledge.

Hansen and Lema (2019) compare concurrent changes in capabilities and learning mechanisms in the Chinese wind-turbine and Malaysian biomass-boiler industries. They provide a number of relevant insights. For example, they find (i) that learning based on firminternal sources alone constrains the capability-building that firms undergo, (ii) that advances to higher levels of capabilities usually involve some form of foreign knowledge input, and (iii) that learning mechanisms at lower capability levels are primarily based on commercial activities, while those at higher levels frequently stem from R\&D efforts. However, all these results are presented at the sectoral level, which means that they do not provide much insight regarding inter-firm heterogeneity in these dynamics.

Thus, it appears that, despite a longstanding scholarship of latecomer capability-building processes, the line of investigation into how learning activities change as capability stocks deepen is still in its infancy. As Bell and Figueiredo (2012: 69) put it:

"We know little about the relative importance of different learning mechanisms and even less about whether and how this varies as firms deepen their innovative capabilities. Without this understanding, the field lacks even a rudimentary basis for offering insights about the practicalities of managing learning in latecomer firms (...)."

Given the heterogeneous nature of capability-building processes (Figueiredo, 2017; Lall, 1992), we approach this topic from a micro-level perspective, focusing on the level of the firm. This can provide important insights informing the design of policies to effectively support the localisation of clean-tech industries in the countries of the Global South.

\section{Biogas in Thailand}

In this paper, we present a comparative study of capability building and learning in the Thai biogas industry. The design of an industrial-scale biogas system is primarily determined by the characteristics and availability of feedstocks, which include agricultural, industrial, and municipal wastes and purpose-grown crops (Bachmann, 2013). The heart of a biogas plant is the anaerobic digestion reactor unit where microbes transform feedstock into biogas. Most biogas systems also incorporate additional equipment for substrate pre-treatment, reactor effluent treatment, biogas upgrading, and/or biogas utilisation. In addition to feedstock characteristics, the design of a plant also depends on a variety of other factors, including the client's available resources, local waste management regulations, and how the resulting biogas is used.

The supply of biogas systems involves a variety of organisations. The lead engineering firm is the main organisation of interest here. It provides services in process engineering (choosing technological equipment, dimensions, and layout), mechanical, electrical, and instrument engineering (supplying, installing, and commissioning equipment), and civil engineering (site preparation, soil analysis, etc.) (Rahayu et al., 2015). The lead engineering company typically also sets up the contracts with partner organisations involved in the project. This can include project hosts, operation and maintenance teams, construction companies, specialised consultants, and suppliers of components such as tanks, membranes, mixing equipment, pipes and valves, sensors, and electrical equipment. 
The Thai biogas sector is well suited for a study of latecomer capability building, as it experienced rapid growth in the 1990s and 2000s (Siteur, 2012; Suwansari et al., 2015). Today, Thailand is one of the largest biogas producers in the world and has the largest biogas market in the Global South after China (Figure 2). The country hosts about 1,500 industrialscale biogas plants at livestock farms, palm-oil mills, tapioca starch-processing facilities, and other agro-processing plants (Table 2). Biogas plays an important part in the Thai government's strategy to transition towards a secure and low-carbon energy system (Table 3; see also International Renewable Energy Agency (2017)).

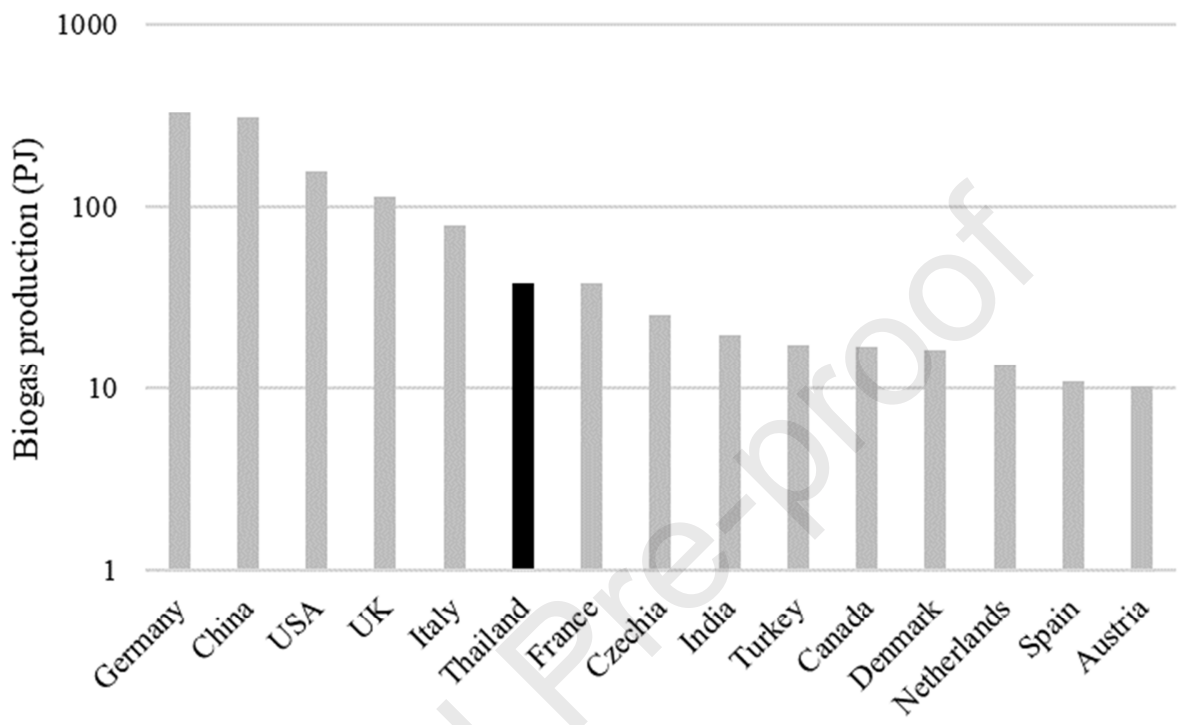

Figure 2. Biogas production of the fifteen highest-producing countries. 2017 data retrieved from International Energy Agency (2020). Logarithmic scale.

\begin{tabular}{l|l|l} 
Host facility type & Number of biogas plants & Biogas production (PJ/year) \\
\hline Livestock farms & 1,250 & 4.69 \\
\hline Palm-oil mills & 72 & 3.82 \\
\hline Starch-processing facilities & 56 & 7.85 \\
\hline Ethanol-production facilities & 19 & 5.25 \\
\hline Other & 80 & 2.73
\end{tabular}

Table 2. Estimated number of biogas plants and biogas production by type of host facility. Source: Energy Research and Development Institute Nakornping and Chiang Mai University (2017), cited in Mehner et al. (2017: 65). Conversion from biogas production in $\mathrm{Nm}^{3}$ to PJ assuming an average energy density factor of 21.6 $\mathrm{MJ} / \mathrm{Nm}^{3}$ following the World Bioenergy Association (2017). 


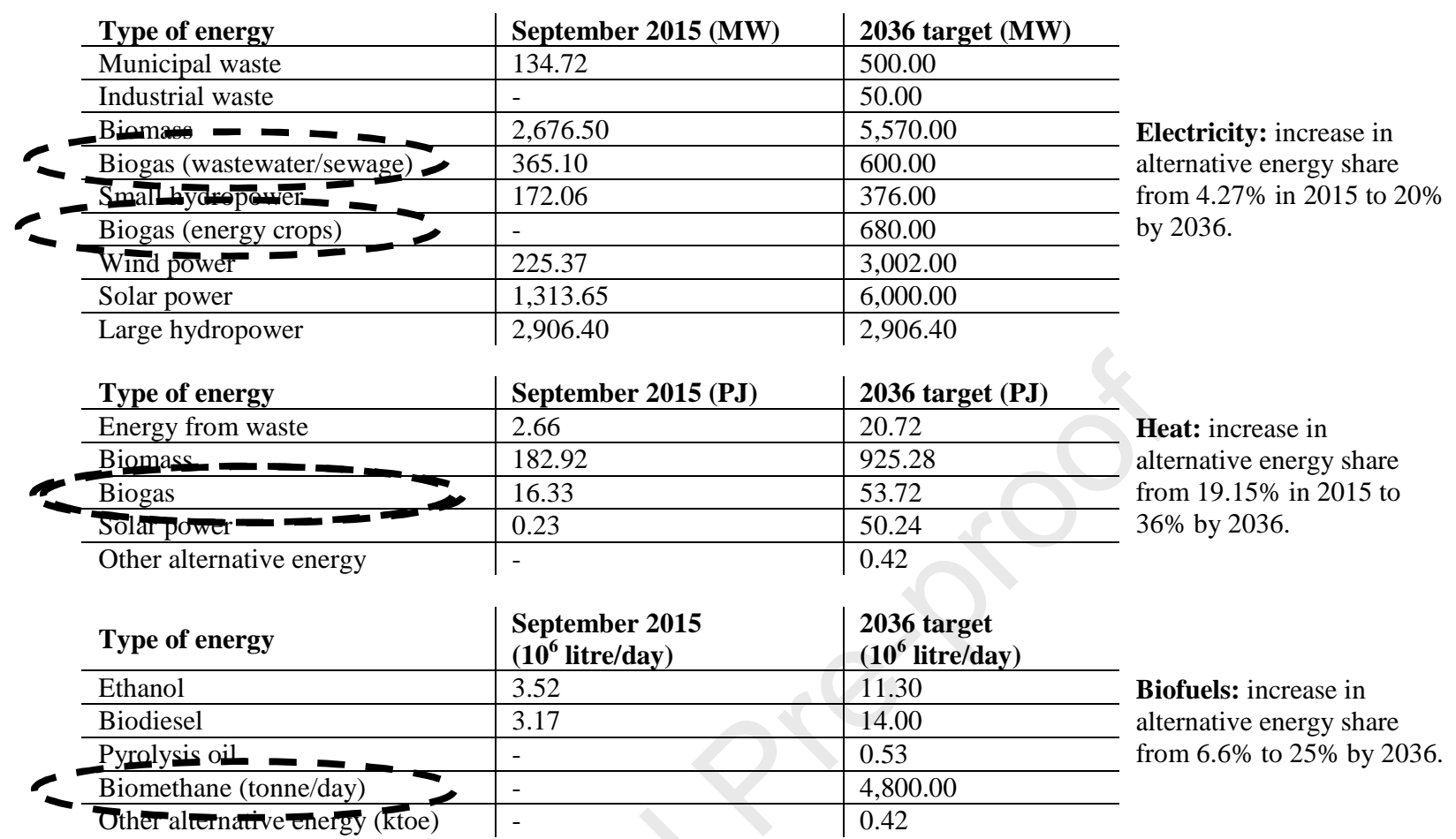

Table 3. Planned increases in capacity and production of renewable energy under Thailand's Alternative Energy Development Plan. Source: Energy Policy Planning Office (2016).

\section{Methodology}

\subsection{Multiple-case study design}

A qualitative case study approach was considered a suitable research design for this paper as it involves exploratory research on a phenomenon that has not been previously explored in detail, and where the context is difficult to separate from the study object (Yin, 2003). As the remainder of the present section explains, the paper offers a comparative account of nine firms on the basis of detailed empirical data and the analytical framework outlined in Section 2. In so doing, it aims to contribute to theory building by using analytical generalisation to develop theoretically relevant propositions (Eisenhardt and Graebner, 2007).

Multiple-case studies have been used in a number of previous studies on latecomer capability-building processes due to their ability to illuminate the relationship between capability-building and learning mechanisms across several firms (e.g., Figueiredo, 2017; Hansen and Ockwell, 2014; Scott-Kemmis and Chitravas, 2007). The inclusion of multiple case firms allows for interesting comparisons, including the identification of commonalities as well as differences across the firms under study (Vannoni, 2015). To this end, we made use of the so-called maximum variation sampling method (Seawright and Gerring, 2008), which involves the selection of a small number of cases that maximize the diversity relevant to the research question while recognising the possibly of identifying common patterns. Such 
an approach generally contributes to enhance the reliability of the findings by allowing for the elimination of potential biases, for example, related to national or sectoral circumstances.

\subsection{Data collection and sample}

The core data for this research were collected during fieldwork in Thailand from May to August 2017. We conducted interviews with representatives of nine biogas engineering firms. We identified these organisations by consulting industry experts in Thailand and by using a snowballing method. Additionally, we conducted interviews with five organisations providing complementary services to biogas systems and held numerous informal conversations with industry participants at a regional renewable-energy trade fair in Bangkok in June 2017.

The present paper is primarily based on our interviews with the nine biogas engineering firms. Key details of these organisations have been anonymised due to confidentiality concerns. The interviews were conducted with leading personnel in the managerial and technical divisions of the firms, lasted between 50 and 120 minutes, and were based on a semi-structured design (see Appendix A for additional information on the interviews). Following questions about the historical backgrounds and business profiles of the firms, interviewees were asked to identify the most relevant technological milestones and breakthroughs that their firms had achieved during their lifetimes. These milestones were subsequently discussed in detail one by one with respect to the technological capabilities they implied and the learning mechanisms they involved (see Appendix B for the complete interview protocol). Interviews were audio recorded and transcribed. The resulting transcripts formed the core source of data for the analysis presented in this paper.

To address the risks of social desirability and recall bias, the authors used the available documentary evidence to triangulate the information obtained during the interviews. This included company brochures and webpages, the technical and academic literature, patents, news articles, industry periodicals, and data from the documentation of Thai biogas projects under the Clean Development Mechanism (CDM) (UNFCCC, 1998). These were identified and accessed via online searches, through referrals by study participants, and by collecting physical copies during visits at the firms' facilitates. As many of the company representatives commented on the activities of their competitors during the interviews, we used this as an additional source of information to triangulate our interview data. In some instances, we contacted interviewees after the fieldwork to request clarification or additional information.

Table 4 provides some background information on our nine case firms. While most of these are local, one is a subsidiary of a foreign-based multinational (Iota). All firms in the sample are privately owned, except for one publicly owned research institute that operates as a technology supplier (Zeta).

While there does not appear to be any comprehensive information about the actors involved in the Thai biogas industry, we are aware of a total of thirty-one biogas technology-supplying firms operating in Thailand. This means that our sample covers about $30 \%$ of the entire industry. To ensure that this includes all relevant firms, we reviewed the available evidence on the development of the Thai biogas industry (Mehner et al., 2017; Siteur, 2012; Suwansari et al., 2015). Furthermore, virtually all of the interviewees mentioned the names of their key competitors, which was used as further confirmation that all the relevant firms had been identified. 
In the absence of information about market shares, we used data on Thai biogas CDM projects to get a sense of the firms' importance to the sector (see Reinauer (2019) for more information). Table 4 gives the shares of CDM projects that each firm was involved in. Fourteen other firms that are not included in the present analysis have supplied biogas technology to CDM projects in Thailand (ibid.). None of these have been involved in more than $3 \%$ of the total number of CDM projects. This suggests that the firms included here are likely to include the most relevant ones to have been involved in the Thai biogas sector, at least during the period when the CDM was active (i.e. roughly 2004-2012; see UNFCCC (2014)).

\begin{tabular}{l|l|l|l|l|l} 
Firm & Employees & Founded & Ownership & Type & $\begin{array}{l}\text { Percentage of Thai biogas CDM } \\
\text { projects for which the firm supplied } \\
\text { biogas systems (total: 117) }\end{array}$ \\
\hline Alpha & $11-50$ & $2005-2009$ & Local & Private sector & 0 \\
\hline Beta & $11-50$ & $2000-2004$ & Local & Private sector & 4 \\
\hline Gamma & $51-100$ & $1990-1994$ & Local & Private sector & 18 \\
\hline Delta & $1-10$ & $2000-2004$ & Local & Private sector & 8 \\
\hline Epsilon & $101-200$ & $1995-1999$ & Local & Private sector & 4 \\
\hline Zeta & $51-100$ & $1990-1994$ & Local & Public research institute & 21 \\
\hline Eta & $101-200$ & $2000-2004$ & Local & Private sector & 2 \\
\hline Theta & $1-10$ & $2010-2014$ & Local & Private sector & 1 \\
\hline Iota & $101-200$ & $2000-2004 *$ & Foreign & Private sector & 4 \\
\hline Sum & - & - & - & - & 62
\end{tabular}

Table 4. Information about firms included in the study. Data sources: interview data and Thai biogas CDM project documentation. *: first year of involvement in Thai biogas sector.

\subsection{Operationalisation of key concepts}

We adopt a broad understanding of technological capabilities as those required for products, processes, equipment, and linkages. There are a number of reasons for this choice. First, we developed the analytical framework for our study with a view to focusing on the empirical case. The Thai biogas industry is a project-based industry, which means that capabilities for product design, process engineering, and equipment overlap strongly (see Kiamehr (2017: 221) for a similar argument). At the same time, the supply of project-based technologies usually involves collaborations between multiple partners (lead engineering firms, construction companies, component suppliers, specialised consultants, etc.), which is why we include linkage capabilities. Finally, we decided to omit capabilities for strategy and investment-related activities because of the need to keep our multi-firm comparison of capability stocks and learning mechanisms tractable.

As the constituents of a firm's technological capabilities (knowledge bases, skills, and experience) are difficult to observe directly, we rely on the "revealed capabilities" approach, which involves inferring a firm's capability stocks from information about the activities in which it engages (Bell and Figueiredo, 2012: 50). For this purpose, we drew up a comprehensive list of relevant indicators, related to the inputs, performance, and outputs of firms' routine and innovation activities (Table 5; see Appendix $\mathrm{C}$ for additional information). This distinguishes our paper from previous studies of latecomer capabilities, which often provide little information on the underlying factors they consider when assessing firm capabilities. We developed this list based on an iterative process of consulting the academic literature and the data collected as part of this research. Prior to the fieldwork, we compiled a comprehensive list of possible indicators based on the literature on latecomer capability accumulation (e.g., Amsden and Tschang, 2003; Bell and Figueiredo, 2012; Figueiredo, 2003; Hansen and Ockwell, 2014). When conducting our interviews, we continuously 
updated this list to reflect the most relevant indicators. Thus, we developed the list presented in Table 5 specifically with the empirical case of the present study in mind.

\begin{tabular}{|c|c|c|}
\hline $\begin{array}{l}\text { Aspect of } \\
\text { innovation } \\
\text { process }\end{array}$ & Indicator & Description \\
\hline \multirow[t]{2}{*}{ Inputs } & $\begin{array}{l}\text { Staff } \\
\text { qualifications }\end{array}$ & $\begin{array}{l}\text { The qualifications of staff are used as a measure of the knowledge, skills, and } \\
\text { experience that a firm possesses. Qualifications are determined based on two } \\
\text { dimensions: the type of degree/training that staff have completed, and the levels } \\
\text { of experience in biogas or related sectors that they have accumulated. }\end{array}$ \\
\hline & $\begin{array}{l}\text { Collaborations } \\
\text { with external } \\
\text { partners }\end{array}$ & $\begin{array}{l}\text { Following Lall (1992), information on collaborations with external partners is } \\
\text { used as an indicator of the firm's linkage capabilities, i.e. its ability to establish } \\
\text { connections to other organisations that allow for the transmission of information, } \\
\text { skills, and equipment. Collaborations are distinguished by type, intensity, and } \\
\text { continuity. }\end{array}$ \\
\hline \multirow[t]{2}{*}{ Performance } & $\begin{array}{l}\text { Methods and } \\
\text { tools }\end{array}$ & $\begin{array}{l}\text { Following Amsden and Tschang (2003), methods and tools refer to the particular } \\
\text { kinds of activities that firms engage in during innovation processes, e.g., the use } \\
\text { of particular methods to test substrates, to experiment with new designs, etc. } \\
\text { These are distinguished based on the complexity of the required knowledge bases } \\
\text { and the amount of required experience. }\end{array}$ \\
\hline & $\begin{array}{l}\text { R\&D and } \\
\text { design and } \\
\text { engineering } \\
\text { activities }\end{array}$ & $\begin{array}{l}\text { Following Amsden and Tschang (2003) and Radosevic and Yoruk }(2018,2016) \text {, } \\
\text { the innovative activities of firms are distinguished based on the kinds of activities } \\
\text { along the innovation chain they involve (basic or applied research, exploratory or } \\
\text { advanced development, or product engineering). }\end{array}$ \\
\hline \multirow[t]{8}{*}{ Outputs } & Awards & $\begin{array}{l}\text { Awards are used as indicators of the firm's ability to develop novel and complex } \\
\text { technology. They are distinguished based on whether they involve national or } \\
\text { international prizes. }\end{array}$ \\
\hline & Exports & $\begin{array}{l}\text { Exports are interpreted as an indication of the firm's ability to participate in } \\
\text { competitive international markets (e.g., see Ernst et al., 1998). Furthermore, they } \\
\text { are seen as an indicator of the firm's ability to develop systems that are suitably } \\
\text { adapted to circumstances that differ from those found in Thailand. Exports are } \\
\text { distinguished based on the number of projects and the regions where they take } \\
\text { place (neighbouring countries in Southeast Asia, other low/middle-income } \\
\text { regions, high-income regions). }\end{array}$ \\
\hline & Patents & $\begin{array}{l}\text { Patents are understood to be an indication of the firm's ability to develop } \\
\text { technology that meets the novelty criteria for patentability. They are differentiated } \\
\text { based on whether they are national patents or EPO/USPTO patents, assuming that } \\
\text { the latter involve more substantial novelty, complexity, and potential economic } \\
\text { impact. }\end{array}$ \\
\hline & $\begin{array}{l}\text { Performance } \\
\text { standards }\end{array}$ & $\begin{array}{l}\text { Following Radosevic and Yoruk (2018), ISO } 9001 \text { certificates are used as an } \\
\text { indicator of high operational efficiency and thus of the presence of high-level } \\
\text { routine production capabilities. In addition, the study also considers ISO } 17025 \\
\text { certificates to be indicators of routine capabilities. These concern quality } \\
\text { standards at testing and calibration laboratories (International Organisation for } \\
\text { Standardization, 2018) and are therefore relevant for the biogas industry. }\end{array}$ \\
\hline & $\begin{array}{l}\text { Product } \\
\text { innovations }\end{array}$ & $\begin{array}{l}\text { This indicator ranks innovations according to their novelty and scope of change. } \\
\text { With regards to the former, the study distinguishes between new-to-firm, new-to- } \\
\text { market, and new-to-world innovations (OECD, 2005). The scope of change is } \\
\text { determined by comparing the different kinds of innovations in which the firms } \\
\text { included in this study have engaged. }\end{array}$ \\
\hline & Reactors - size & $\begin{array}{l}\text { The size of the reactor is interpreted as an indicator of the complexity of the } \\
\text { systems that a firm can handle. While Ariffin and Figueiredo (2004: 580) point } \\
\text { out that one ought to differentiate between a firm's ability (i) to creatively engage } \\
\text { with technology, and (ii) to handle technological complexity, we argue that } \\
\text { handling complex technological systems requires an element of creative } \\
\text { engagement, e.g., with respect to the need to adapt technological designs to } \\
\text { project contexts. Reactors are allocated to one of three categories: small, medium, } \\
\text { or large. }\end{array}$ \\
\hline & $\begin{array}{l}\text { Reactors - } \\
\text { variety }\end{array}$ & $\begin{array}{l}\text { The variety of reactors that a firm offers are seen as an indicator of the breadth of } \\
\text { the firm's knowledge base. A broad knowledge base allows firms to offer various } \\
\text { system designs that are appropriate for different project contexts. Firms are } \\
\text { categorised based on the number of different reactor types they have developed. }\end{array}$ \\
\hline & $\begin{array}{l}\text { Scientific } \\
\text { publications }\end{array}$ & $\begin{array}{l}\text { Scientific publications are seen as an indicator of the firm's capability to } \\
\text { undertake basic and applied research. Data for this indicator are distinguished } \\
\text { based on the frequency of research outputs and the quality of the outlets in which }\end{array}$ \\
\hline
\end{tabular}




\begin{tabular}{|l|l}
\hline Substrates & $\begin{array}{l}\text { they are published. } \\
\text { information on the variety of substrate types that a firm has worked with provides } \\
\text { insights into the breadth of its knowledge base. In addition, the amount of dry- } \\
\text { matter content of substrates is seen as an indicator of the firm's ability to handle } \\
\text { technological systems that require sophisticated technological know-how (source: } \\
\text { multiple interviews conducted for this study). }\end{array}$ \\
\hline $\begin{array}{l}\text { System } \\
\text { performance }\end{array}$ & $\begin{array}{l}\text { System performance is used as an indicator of routine capabilities, i.e. the firm's } \\
\text { ability to supply well-functioning technological systems. A simple distinction is } \\
\text { made between systems that operate well and those that do not. }\end{array}$ \\
\hline $\begin{array}{l}\text { Trademarks } \\
\text { service }\end{array}$ & $\begin{array}{l}\text { Following Mendonça et al. (2004), trademarks are used as an indicator of the } \\
\text { firm's ability to offer differentiated products and are thus seen as an indicator of } \\
\text { high-level routine production capabilities. }\end{array}$ \\
\hline $\begin{array}{l}\text { Finally, the types of services that firms engage in are considered to reveal further } \\
\text { information about their capability levels. In particular, firms that are hired to fix } \\
\text { under-performing biogas systems which were previously developed by } \\
\text { competitors are considered to enjoy a good reputation for their technical } \\
\text { capabilities among clients. As such, companies that have offered such revamping } \\
\text { services are considered to exhibit high levels of routine capabilities. }\end{array}$
\end{tabular}

Table 5. List of capability indicators used in the analysis.

Table 6 maps these indicators onto a capability ladder of the type introduced in Section 2.1. The grey shading illustrates the ranges of the capability levels that each individual indicator covers. Determination of these ranges was based on the literature of latecomer capabilities, the technical literature on biogas systems, and our own understanding of routine production and innovation processes in the biogas industry. Detailed explanations for how the ranges for each indicator were determined are included in Appendix C.

\begin{tabular}{|c|c|c|c|c|c|c|c|}
\hline \multirow{2}{*}{$\begin{array}{l}\text { Aspect of } \\
\text { innovation } \\
\text { process }\end{array}$} & \multirow[t]{2}{*}{ Indicator } & \multicolumn{2}{|c|}{ Routine } & \multicolumn{4}{|c|}{ Innovative } \\
\hline & & Basic & $\begin{array}{l}\text { Extra } \\
\text { basic }\end{array}$ & Basic & $\begin{array}{l}\text { Inter- } \\
\text { mediate }\end{array}$ & Advanced & $\begin{array}{l}\text { World- } \\
\text { leading }\end{array}$ \\
\hline \multirow[t]{2}{*}{ Inputs } & $\begin{array}{l}\text { Staff } \\
\text { qualifications }\end{array}$ & & & & & & \\
\hline & $\begin{array}{l}\text { Collaborations } \\
\text { with external } \\
\text { partners }\end{array}$ & & & & & & \\
\hline \multirow[t]{2}{*}{ Performance } & $\begin{array}{l}\text { Methods and } \\
\text { tools }\end{array}$ & & & & & & \\
\hline & $\begin{array}{l}\text { R\&D and } \\
\text { design and } \\
\text { engineering } \\
\text { activities }\end{array}$ & & & & & & \\
\hline \multirow[t]{11}{*}{ Outputs } & Awards & & & & & & \\
\hline & Exports & & & & & & \\
\hline & Patents & & & & & & \\
\hline & $\begin{array}{l}\text { Performance } \\
\text { standards }\end{array}$ & & & & & & \\
\hline & $\begin{array}{l}\text { Product } \\
\text { innovations }\end{array}$ & & & & & & \\
\hline & Reactors - size & & & & & & \\
\hline & $\begin{array}{l}\text { Reactors - } \\
\text { variety }\end{array}$ & & & & & & \\
\hline & $\begin{array}{l}\text { Scientific } \\
\text { publications }\end{array}$ & & & & & & \\
\hline & Substrates & & & & & & \\
\hline & $\begin{array}{l}\text { System } \\
\text { performance }\end{array}$ & & & & & & \\
\hline & Trademarks & & & & & & \\
\hline
\end{tabular}


Table 6. Mapping capability indicators to capability levels.

Aggregating information on individual indicators into an overall capability score for each firm was done using the following steps. First, each piece of information about capability indicators was ranked according to the ranges of the illustrated capability levels. Next, each piece of information was assigned a year, which allowed temporal ordering and the development of detailed capability biographies for each firm. Using these biographies, we then divided each firm's lifetime into different stages, determined based on notable changes (milestones) in the types of projects in which firms engaged. Finally, we determined a single, overall capability level for each lifetime stage of each firm based on the information available from the indicators. Basing this on a quantitative weighting system was considered impractical because first, the amounts of information available for the lifetime stages of the firms are inconsistent, and secondly, there is no theoretical basis for the choice of weights for individual indicators. Thus, we decided to aggregate the information from the individual indicators for a particular firm and lifetime stage based on our understanding of the biogas industry and on a comparative analysis of the firms included in this study.

As with the list of capability indicators, we also developed a list of relevant learning mechanisms by iteratively consulting the literature on latecomer capability and the information obtained from the interviews (see Table 7). As described in Section 2.2, we distinguish learning mechanisms by origin and type. Following the same procedure that we used to structure our data on capability indicators, each piece of empirical information was assigned a year, which allowed us to develop learning mechanism biographies for each firm. Based on the year that an individual piece of information was assigned, it was then allocated to one of the firms' lifetime stages highlighted above. The capability and learning biographies form the basis for the analysis presented in the following section of this paper.

\begin{tabular}{|c|c|c|c|}
\hline Type & Internal & External-domestic & External-foreign \\
\hline $\begin{array}{l}\text { Commercially } \\
\text { driven }\end{array}$ & $\begin{array}{l}\text { - Learning by doing on a } \\
\text { project-to-project basis } \\
\text { - Learning by using through } \\
\text { operation of projects } \\
\text { - Learning through } \\
\text { systematic collection and } \\
\text { analysis of operational data }\end{array}$ & $\begin{array}{l}\text { - Learning through } \\
\text { observation of project } \\
\text { developed by local company } \\
\text { - Learning through operation } \\
\text { of project developed by } \\
\text { local company } \\
\text { - Learning by acquisition of } \\
\text { project developed by local } \\
\text { company } \\
\text { - Learning through } \\
\text { collaboration with local } \\
\text { component supplier } \\
\text { - Learning through } \\
\text { collaboration with local } \\
\text { engineering and construction } \\
\text { company } \\
\text { - Learning through } \\
\text { collaboration with local } \\
\text { biogas expert } \\
\text { - Learning from user } \\
\text { feedback }\end{array}$ & $\begin{array}{l}\text { - Learning through } \\
\text { observation of project } \\
\text { developed by foreign } \\
\text { company } \\
\text { - Learning through operation } \\
\text { of project developed by } \\
\text { foreign company } \\
\text { - Learning through } \\
\text { acquisition of project } \\
\text { developed by foreign } \\
\text { company } \\
\text { - Learning through } \\
\text { collaboration with foreign } \\
\text { component supplier } \\
\text { - Learning through } \\
\text { collaboration with foreign } \\
\text { engineering and construction } \\
\text { company } \\
\text { - Learning by collaborating } \\
\text { with foreign biogas system } \\
\text { designer }\end{array}$ \\
\hline R\&D-driven & $\begin{array}{l}\text { - Learning through testing in } \\
\text { laboratory } \\
\text { - Learning through on-site } \\
\text { testing }\end{array}$ & $\begin{array}{l}\text { - Learning through } \\
\text { collaboration with local } \\
\text { testing facility } \\
\text { - Learning through research }\end{array}$ & $\begin{array}{l}\text { - Learning through } \\
\text { consultation of the academic } \\
\text { and technical literature } \\
\text { - Learning through }\end{array}$ \\
\hline
\end{tabular}




\begin{tabular}{l|l|l|l} 
& $\begin{array}{l}\text { - Learning through trial and } \\
\text { error experimentation } \\
\text { - Learning through testing at } \\
\text { pilot-scale plant }\end{array}$ & $\begin{array}{l}\text { collaboration with local } \\
\text { organisation }\end{array}$ & $\begin{array}{l}\text { collaboration with foreign } \\
\text { testing facility } \\
\text { - Learning through research } \\
\text { collaboration with foreign } \\
\text { organisation }\end{array}$ \\
\hline $\begin{array}{l}\text { Human } \\
\text { resource- } \\
\text { related }\end{array}$ & $\begin{array}{l}\text { - Education and experience } \\
\text { of founding members }\end{array}$ & $\begin{array}{l}\text { - Learning by hiring staff } \\
\text { educated at local university } \\
\text { and/or with experience of } \\
\text { local organisation }\end{array}$ & $\begin{array}{l}\text { - Learning by hiring staff } \\
\text { educated at foreign } \\
\text { university and/or with } \\
\text { experience of foreign } \\
\text { organisation }\end{array}$
\end{tabular}

Table 7. List of learning mechanisms used in the analysis.

\section{Results}

We present our results in three parts. Section 5.1 summarises the data on the capability trajectories the nine case-study firms. This addresses the first research question mentioned in Section 2: What types of knowledge and skills have Thai biogas system suppliers acquired through internal and external learning? Section 5.2 summarises the learning mechanisms that these firms have engaged in, thus addressing the second research question: How have they acquired these? Section 5.3 combines the data on capability trajectories and learning mechanisms to answer the question: How do learning mechanisms change as latecomers build higher levels of technological capabilities?

\subsection{Capability development pathways}

Aside from the foreign-owned subsidiary (Iota) and one local firm (Theta), all firms started out at relatively low levels of capability development, ranging from the basic routine to the basic innovative stages (Figure 3). All of these firms have transitioned towards higher levels of capability during the study period. We divided our case-study firms into three groups according to similarities in their capability development pathways. The remainder of this subsection summarises the developments in the three groups' capability building efforts. Given word count limitations, we focus our summary on key capability indicators. 


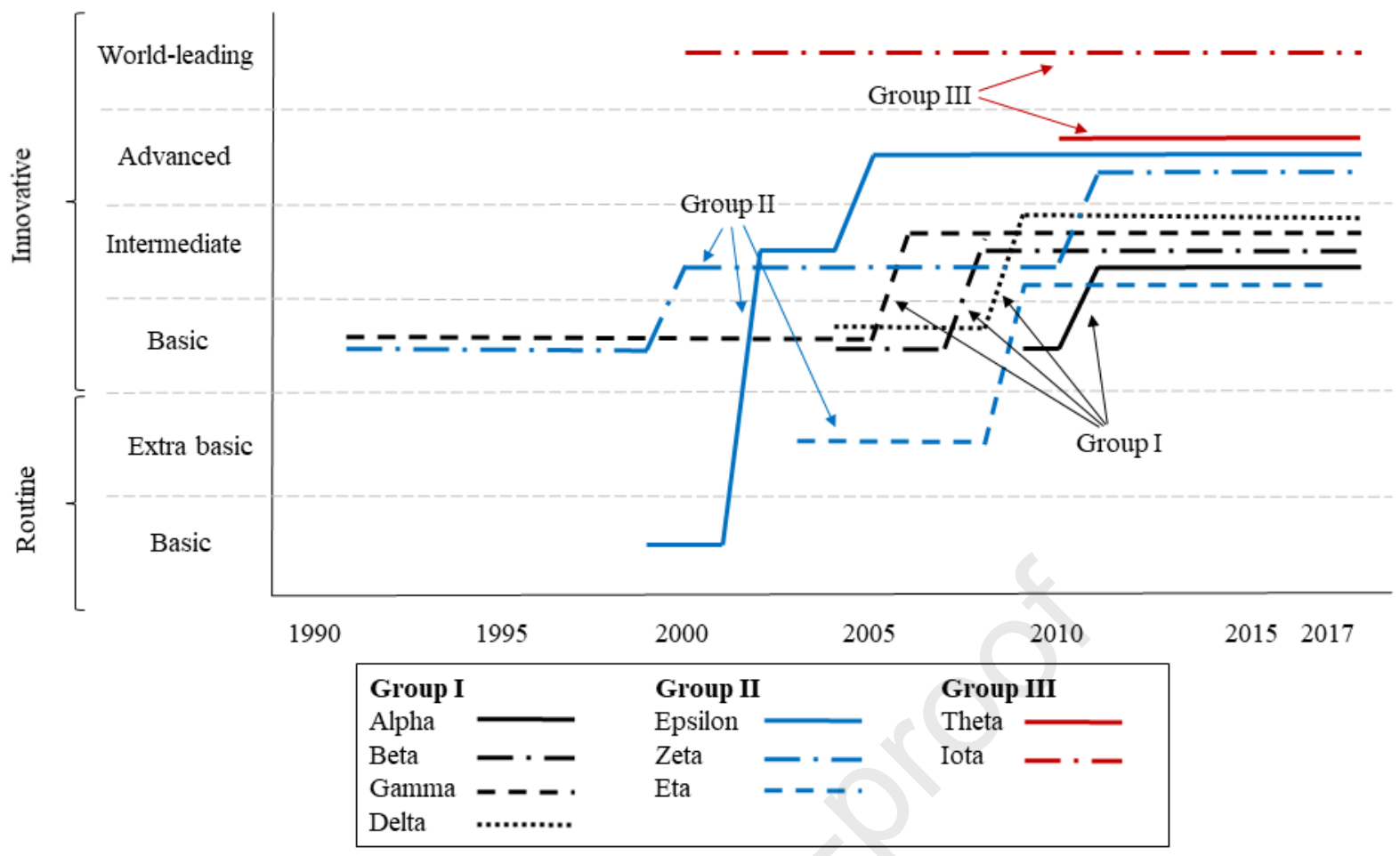

Figure 3. Capability development pathways for case-study firms in the Thai biogas industry.

Group I includes four firms (Alpha, Beta, Gamma, and Delta) that have achieved modest improvements in their capability stocks during the study period, from the basic to the intermediate innovative capability category. In the early stages of their lifetimes, each of these firms worked with only a single reactor type and a limited range of substrates. Gamma and Delta developed pilot plants in collaboration with local universities to test their designs before applying them in commercial projects. Alpha and Beta adopted foreign designs and introduced changes to these to address the particularities of local substrates. This involved relatively minor adaptations to prevent clogging inside the reactor by introducing an improved substrate mixing mechanism (Alpha) and a device to scrape out settled solids (Beta). In the later stages of their lifetimes, all four firms moved to the intermediate level of capabilities. During this period, they adopted small varieties of reactor designs and experimented with new substrate types (all four companies), pre-treatment technologies (Alpha), and biogas usage options (Gamma). This has resulted in a range of innovations, some of which involve technologies not previously used in Thailand. With respect to linkage capabilities, the firms interacted with local testing facilities (Alpha and Gamma), foreign component suppliers (Alpha, Beta), and foreign biogas experts (Gamma) in the later stages of the study period. Our data suggest that instances of technology co-development are rare. Alpha is the only company whose leadership indicated that it had worked with a foreign organisation to adapt a new technology (a substrate pre-treatment process) to the Thai context.

The firms included in Group II (Epsilon, Zeta, and Eta) have achieved more substantial improvements in their capability stocks than those in Group I. While Eta transitioned once from the extra basic routine to the intermediate innovative level, Epsilon and Zeta underwent two transitions and reached the advanced innovative level. In their early stages, all three firms only engaged in limited innovative activity. The interviews revealed that Eta started out as a project operation firm. Epsilon and Zeta initially focused on the development of medium- 
scale pig-manure digesters, for which they had previously obtained designs from foreign partners. According to our interviews, these systems performed poorly due to the absence of an internal substrate-mixing mechanism, which frequently resulted in clogging by settled solids. Our data suggest that all three firms in this group moved towards higher capability levels at later stages in their lifetimes. While Eta began to develop its own biogas systems, Epsilon and Zeta engaged in progressively more novel and complex innovations. Epsilon experienced a particularly sharp increase in its capability stock around the year 2000 when a change in management led to the hiring of two internationally renowned biogas experts and a reorientation of the company from pig manure to the treatment of cassava wastewater. Over the years, Epsilon and Zeta have managed to adopt an increasing range of biogas system designs, which has allowed them to develop projects based on a variety of substrate types. Information available in the documentation of CDM projects revealed that Epsilon's and Eta's systems belong to the largest ones in Thailand. While Zeta and Eta were among the first local firms to export biogas technology into neighbouring countries in Southeast Asia, Epsilon exported a system to a European country and provided consultancy services to a large energy-engineering company based in Japan.

Finally, the firms in Group III (Theta and Iota) exhibit continuously high levels of innovative capabilities at the advanced and world-leading levels. Both firms are headed by experts who each have more than thirty years of international experience in biogas. Our interviews revealed that some of these have been involved in the early developmental stages of reactor designs which today are used across the world. Theta and Iota have strong linkage and R\&D capabilities, which are reflected in their participation in international R\&D programmes that have led to new-to-the-country and, in some cases, new-to-the-world applications. The interview with Iota revealed that the firm maintains a close relationship with a world-leading research centre located in Europe. Furthermore, Iota's interviewee stated that the firm does not usually develop pilot plants because its staff has accumulated sufficient experience to introduce major changes to biogas systems in full-scale, operational projects. These R\&D projects often involve implementing new components from globally leading component manufacturers that are based in high-income countries. Our data show that both firms' biogas systems are among the largest in the world and that some of them were awarded globally renowned prizes. The information available on the firms' webpages illustrates that Theta and Iota work with a wide range of substrates and that they have adopted a substantially larger variety of reactor designs than the firms included in Groups I and II. Both Theta and Iota have developed projects in a variety of countries, both across Southeast Asia and in other low-, middle-, and high-income regions of the world.

\subsection{Engagement in learning mechanisms}

This section presents our data on key learning mechanisms that the nine case-study firms have engaged in during the study period (see Table 8).

The interviewees from the firms included in Group I all stressed that, in the early stages of their lifetimes, their firms relied extensively on the experience of their leading staff members. Additionally, Alpha, Gamma, and Delta mentioned that they gained critical knowledge about design principles by observing and/or operating biogas projects that had previously been developed by foreign firms, allowing them to learn about technologically advanced and wellproven designs. Furthermore, the representatives of Gamma and Delta pointed out that they had developed pilot projects at the beginning of their lifetimes, for which they collaborated with a local biogas expert and an MSc student from a local university respectively. Alpha and Beta combined the experience of their key staff members with project-to-project experiences 
and trial-and-error experimentation at project sites. In later stages of their lifetimes, all four firms transitioned from the basic to the intermediate innovative level of capabilities. The interviewees from Alpha, Beta, and Gamma stressed that, during this time, project-to-project experiences, sometimes in combination with trial-and-error experimentation, allowed them to incrementally improve the performance of system designs that they had previously developed. Furthermore, all four firms adopted new-to-firm reactor designs. While Gamma and Delta primarily relied on the experience of their staff for this, the interviewees from Alpha and Beta mentioned that they were able to access detailed technological know-how from foreign suppliers of core components. At the time of the interviews, Alpha was also collaborating with a Chinese company to adapt a potentially new-to-the-country pretreatment method for a novel substrate type. 


\begin{tabular}{|c|c|c|c|c|c|c|c|c|c|c|c|c|c|}
\hline \multirow[t]{2}{*}{ Gr. } & \multirow{2}{*}{ Firm } & \multicolumn{3}{|l|}{ Stage 1} & \multicolumn{3}{|l|}{ Stage 2} & \multicolumn{3}{|l|}{ Stage 3} & \multicolumn{3}{|l|}{ Stage 4} \\
\hline & & Internal & Ext.-dom. & Ext.-for. & Internal & Ext.-dom. & Ext.-for. & Internal & Ext.-dom. & Ext.-for. & Internal & Ext.-dom. & Ext.-for. \\
\hline \multirow[t]{8}{*}{ I } & \multirow{2}{*}{ Alpha } & \multicolumn{3}{|c|}{ 2009-2010: basic innovative } & \multicolumn{3}{|c|}{ 2011-2016: intermediate innovative } & \multicolumn{3}{|c|}{ 2017: intermediate innovative } & & & \\
\hline & & $\begin{array}{l}\text {-Founders' } \\
\text { experience } \\
\text {-Project- } \\
\text { to-project } \\
\text {-Trial-and- } \\
\text { error }\end{array}$ & $\begin{array}{l}\text {-Local hire } \\
\text {-Local } \\
\text { eng./constr. } \\
\text { company }\end{array}$ & $\begin{array}{l}\text {-Operating } \\
\text { foreign } \\
\text { company's } \\
\text { project }\end{array}$ & $\begin{array}{l}\text {-Project-to- } \\
\text { project } \\
\text {-Trial-and- } \\
\text { error } \\
\text {-Pilot } \\
\text { testing }\end{array}$ & $\begin{array}{l}\text {-Local res. } \\
\text { collab. }\end{array}$ & $\begin{array}{l}\text {-Foreign } \\
\text { component } \\
\text { supplier }\end{array}$ & & & $\begin{array}{l}\text {-Int. res. } \\
\text { collab. }\end{array}$ & & & \\
\hline & \multirow[t]{2}{*}{ Beta } & \multicolumn{3}{|c|}{ 2004-2007: basic innovative } & \multicolumn{3}{|c|}{ 2008-2017: intermediate innovative } & & & & & & \\
\hline & & $\begin{array}{l}\text {-Founders' } \\
\text { experience } \\
\text {-Project- } \\
\text { to-project } \\
\text {-Trial-and- } \\
\text { error }\end{array}$ & & $\begin{array}{l}\text {-Foreign } \\
\text { component } \\
\text { supplier }\end{array}$ & $\begin{array}{l}\text {-Project-to- } \\
\text { project }\end{array}$ & & $\begin{array}{l}\text {-Foreign } \\
\text { component } \\
\text { supplier } \\
\text {-Foreign } \\
\text { eng./constr. } \\
\text { company }\end{array}$ & & & & & & \\
\hline & \multirow[t]{2}{*}{ Gamma } & \multicolumn{3}{|c|}{ 1991-2005: basic innovative } & \multicolumn{3}{|c|}{ 2006-2017: intermediate innovative } & & & & & & \\
\hline & & $\begin{array}{l}\text {-Founders' } \\
\text { experience } \\
\text {-Pilot } \\
\text { testing } \\
\text {-Project- } \\
\text { to-project }\end{array}$ & $\begin{array}{l}\text {-Local } \\
\text { biogas } \\
\text { expert } \\
\text {-Local hire }\end{array}$ & $\begin{array}{l}\text {-Technical } \\
\text { literature } \\
\text {-Observe } \\
\text { foreign } \\
\text { company's } \\
\text { project }\end{array}$ & $\begin{array}{l}\text {-Project-to- } \\
\text { project }\end{array}$ & $\begin{array}{l}\text {-Local hire } \\
\text {-Local res. } \\
\text { collab. }\end{array}$ & $\begin{array}{l}\text {-Technical } \\
\text { literature }\end{array}$ & & & & & & \\
\hline & \multirow[t]{2}{*}{ Delta } & \multicolumn{3}{|c|}{ 2004-2008: basic innovative } & \multicolumn{3}{|c|}{ 2009-2017: intermediate innovative } & & & & & & \\
\hline & & $\begin{array}{l}\text {-Founders' } \\
\text { experience } \\
\text { - Pilot } \\
\text { testing } \\
\text {-Trial-and- } \\
\text { error }\end{array}$ & $\begin{array}{l}\text {-Local res. } \\
\text { collab. }\end{array}$ & $\begin{array}{l}\text {-Observe } \\
\text { foreign } \\
\text { company's } \\
\text { project }\end{array}$ & $\begin{array}{l}\text {-Pilot } \\
\text { testing }\end{array}$ & & & & & & & & \\
\hline \multirow[t]{2}{*}{ II } & \multirow[t]{2}{*}{ Epsilon } & \multicolumn{3}{|c|}{ 1999-2001: basic routine } & \multicolumn{3}{|c|}{ 2002-2004: intermediate innovative } & \multicolumn{3}{|c|}{ 2005-2008: advanced innovative } & \multicolumn{3}{|c|}{ 2009-2017: advanced innovative } \\
\hline & & $\begin{array}{l}\text {-Founders' } \\
\text { experience }\end{array}$ & & & $\begin{array}{l}\text {-Project-to- } \\
\text { project } \\
\text {-Project } \\
\text { operation } \\
\text {-Analysing } \\
\text { operational } \\
\text { data }\end{array}$ & & $\begin{array}{l}\text {-Foreign } \\
\text { biogas } \\
\text { system } \\
\text { designer }\end{array}$ & $\begin{array}{l}\text {-Project-to- } \\
\text { project } \\
\text {-Project } \\
\text { operation } \\
\text {-Analysing } \\
\text { operational } \\
\text { data }\end{array}$ & & $\begin{array}{l}\text {-Foreign } \\
\text { hire } \\
\text {-Foreign } \\
\text { component } \\
\text { supplier }\end{array}$ & $\begin{array}{l}\text {-Pilot } \\
\text { testing } \\
\text {-Project- } \\
\text { to-project } \\
\text {-Project } \\
\text { operation } \\
\text {-Analysing } \\
\text { operational } \\
\text { data } \\
\text {-In-house } \\
\text { lab-testing }\end{array}$ & $\begin{array}{l}\text {-Acquiring } \\
\text { local } \\
\text { company's } \\
\text { project }\end{array}$ & $\begin{array}{l}\text {-Foreign } \\
\text { hire } \\
\text {-Foreign } \\
\text { biogas } \\
\text { system } \\
\text { designer } \\
\text {-Acquiring } \\
\text { foreign } \\
\text { company's } \\
\text { project }\end{array}$ \\
\hline
\end{tabular}




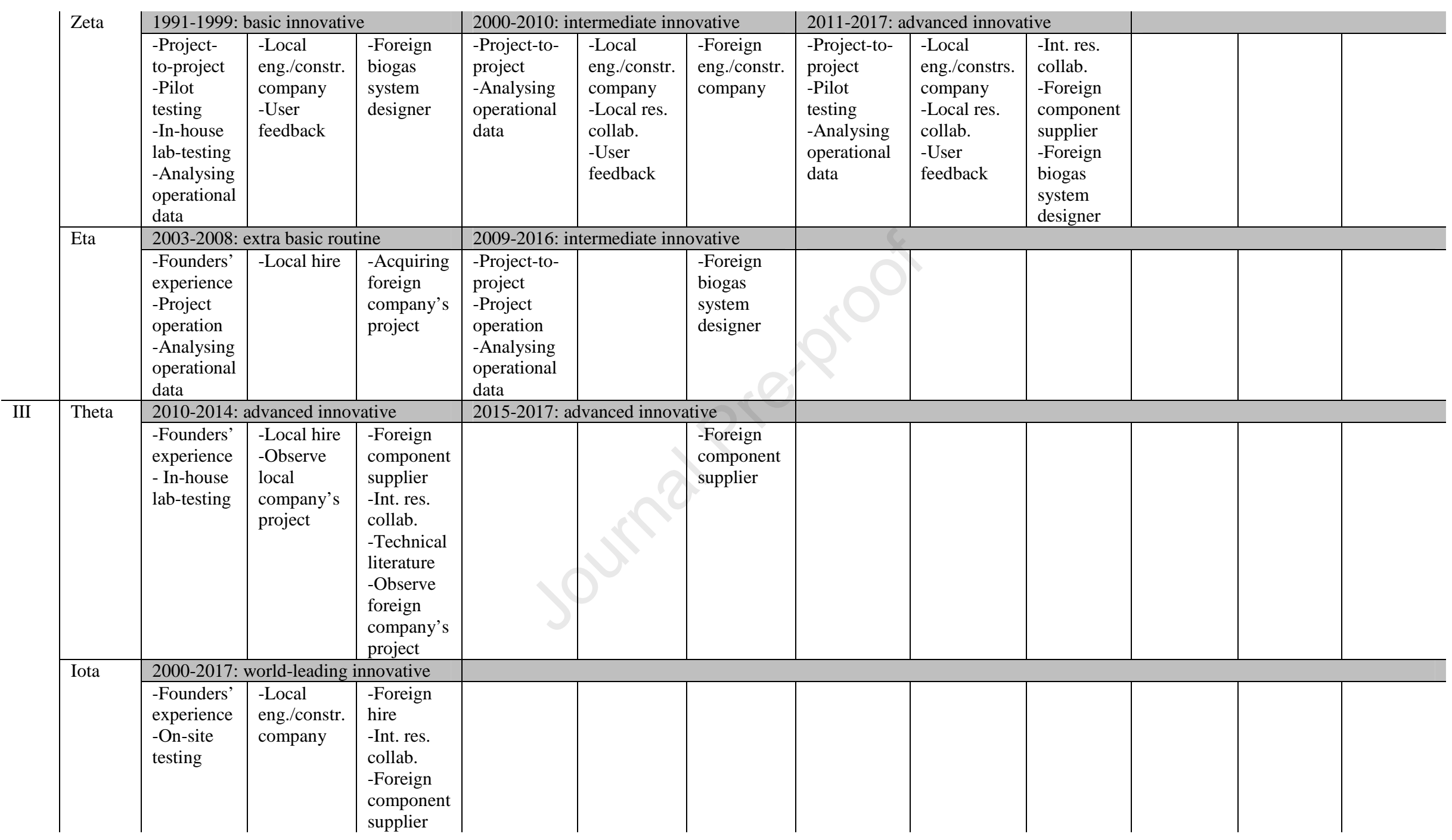

Table 8. Learning mechanisms used by firms across different stages of their lifetimes. Abbreviations: eng./constr., engineering and construction; res. collab., research collaboration. 
We now turn to the learning mechanisms in which the members of Group II have engaged. In the early stages of development of Thailand's biogas sector, Zeta (a public research institute) benefitted from its access to advanced technological knowledge through a collaboration with a large, European-based donor agency. Subsequently, Zeta mainly learnt from developing a large number of projects based on this design knowledge under a government-funded biogas technology-diffusion programme. Our interview with Epsilon revealed that the company initially invested very little in learning, which meant that it was only able to provide relatively small systems that often experienced operational problems. Eta started out as a project-operating company after acquiring a number of projects that had previously been developed by a foreign partner firm. Eta's representatives explained that the company invested heavily in optimising the performance of these projects at the time, which included introducing sophisticated systems for performance monitoring and hiring a local Ph.D. graduate to analyse the resulting data. In later stages of their lifetimes, all three firms in this group upgraded to the intermediate innovative capability level. At this time, Eta began to develop its own systems in collaboration with a foreign-based system-design company. Epsilon also started to collaborate closely with a foreign design company, which was a result of the change in management around the year 2000 mentioned above. From this point onward, Epsilon also repeatedly hired foreign experts to head its technical and managerial units. The interviewees from all three firms in this group emphasised that they continuously invested resources in the collection and analysis of operational data to optimise the performance of their existing systems and to improve designs for new projects. Like Eta, Epsilon began to operate its own projects in the later stages of its lifetime, which facilitated improvements in subsequent projects based on lessons learnt. In the latest stages in their lifetimes, Zeta and Epsilon further upgraded their capability stocks to the advanced innovative level. During this time, both companies engaged in R\&D-based learning, combining in-house laboratory testing with pilot projects to develop designs for substrate types with substantially different characteristics from those they had worked with before. Zeta also collaborated with a world-leading component supplier and a European university in these projects.

Finally, we discuss the learning activities of Group III. As described above, Theta and Iota exhibited high levels of innovative capabilities throughout the study period. Both firms have benefitted substantially from the extensive experience of their senior staff, who have decades of international experience in biogas. The interviewees of both firms highlighted examples of international research collaborations that illustrate their respective capability stocks. Iota regularly collaborates with a team at a European university that is led by a world-leading researcher on anaerobic digestion. The interviewee also mentioned an example of a recent R\&D project that aims to incorporate a key component from a foreign supplier into a new-tothe-world substrate pre-treatment application. As in several of Iota's R\&D projects, this involves on-site testing at fully operational, commercial projects. Theta's interviewees highlighted their participation in an $R \& D$ project funded by a foreign government with the aim of generating new knowledge about biogas cleaning technologies. The interviews with the firms in this group revealed that both had also improved their capabilities by recruiting experienced foreign and domestic staff. Additionally, Iota benefitted from temporarily working with a local engineering firm, which provided it with access to clients and detailed information about local feedstock characteristics.

\subsection{Concurrent changes in capability building and learning}

Now that we have discussed the capability trajectories and learning activities of our casestudy firms, we can investigate potential concurrent changes in these two variables. As shown in Table 9, the amount of information available at different capability levels varies. While the 
basic routine, extra basic routine, and world-leading innovative categories each only give information about a single firm, the intermediate innovative category includes as many as seven firms. This should be kept in mind when interpreting the results.

Epsilon is the only firm that exhibited capabilities of the basic routine class. In the early stages of its lifetime, it exclusively built biogas systems for the treatment of pig manure. According to the firm's representative, virtually all of these systems under-performed. At the time, Epsilon engaged in very limited learning, mostly revolving around the knowledge and experience of its founding members. It did not engage in any other learning mechanisms based on firm-internal or external sources of knowledge.

Eta is the only company that falls into the extra basic routine level of capabilities (in the first stage of its lifetime). As argued above, it has invested substantially in learning. This included acquiring projects that had previously been developed by a foreign-based company, operating these projects, collecting and analysing performance data, and hiring a local Ph.D. graduate. The combination of these mechanisms allowed Eta to develop a detailed understanding of the designs of these systems. In later stages of its lifetime, Eta used this knowledge to develop its own projects. Eta's investments in learning while it was at the extra-basic routine level of capabilities contrast sharply with the limited learning that Epsilon has engaged in while it was at the basic level of routine capabilities.

Alpha, Beta, Gamma, Delta, and Zeta exhibited basic innovative capabilities in the course of their lifetimes. Our data show that nearly all representatives of these firms highlighted the importance of learning on a project-to-project basis, sometimes combined with trial-and-error experimentation with full-scale projects (Alpha, Beta, Gamma, Zeta). Three of the five firms developed pilot plants to test and experiment with new reactor designs or key components, which sometimes also involved collaborations with local or foreign partners (Gamma, Delta, Zeta). Three firms in this group indicated that they learnt by observing and/or operating projects developed by foreign companies (Alpha, Gamma, and Delta). In general, firms at the basic innovative capability level indicated that they have learnt from domestic sources of external knowledge more frequently than from foreign sources. While domestic sources of learning involved a variety of types (productivity-driven, innovation-driven, and humanresource-focused), learning involving foreign sources of knowledge hardly involved any R\&D. Instead, foreign-based learning revolved around human resources and productivitydriven efforts.

Seven firms have achieved innovative capabilities at the intermediate innovative level (Alpha, Beta, Gamma, Delta, Epsilon, Zeta, and Eta). Compared to the basic innovative level, this level is characterised by a higher share of firms that actively collected and analysed performance data to learn how to improve designs in subsequent projects. In two of these cases, the firms themselves operated the projects that they developed (Epsilon and Eta). Furthermore, compared to the previously discussed capability levels, the intermediate innovative level is characterised by a lower range of learning mechanisms based on domestic sources of knowledge. This predominantly revolved around research collaborations with local research centres (Alpha, Gamma, and Zeta). Other forms of domestic interactive learning are rare. The firms at this level of capabilities more frequently learnt from foreign sources of knowledge. This included collaborations with component suppliers (Alpha and Beta), engineering and construction companies (Beta and Zeta), and biogas system designers (Epsilon and Eta). Research collaborations with foreign organisations are rare (only Alpha in recent

years). 


\begin{tabular}{|c|c|c|c|c|}
\hline $\begin{array}{l}\text { Capability } \\
\text { level }\end{array}$ & Firm & $\begin{array}{l}\text { Learning mechanism } \\
\text { Internal }\end{array}$ & External-domestic & External-foreign \\
\hline $\begin{array}{l}\text { Basic } \\
\text { routine }\end{array}$ & Epsilon & -Founders' experience & & \\
\hline $\begin{array}{l}\text { Extra basic } \\
\text { routine }\end{array}$ & Eta & $\begin{array}{l}\text {-Founders' experience } \\
\text {-Project operation } \\
\text {-Analysing operational data }\end{array}$ & -Local hire & $\begin{array}{l}\text {-Acquiring foreign } \\
\text { company's project }\end{array}$ \\
\hline \multirow[t]{5}{*}{$\begin{array}{l}\text { Basic } \\
\text { innovative }\end{array}$} & Alpha & $\begin{array}{l}\text {-Founders' experience } \\
\text {-Project-to-project } \\
\text {-Trial-and-error }\end{array}$ & $\begin{array}{l}\text {-Local hire } \\
\text {-Local eng./constr. company }\end{array}$ & $\begin{array}{l}\text {-Operating foreign } \\
\text { company's project }\end{array}$ \\
\hline & Beta & $\begin{array}{l}\text {-Founders' experience } \\
\text {-Project-to-project } \\
\text {-Trial-and-error }\end{array}$ & & -Foreign component supplier \\
\hline & Gamma & $\begin{array}{l}\text {-Founders' experience } \\
\text {-Pilot testing } \\
\text {-Project-to-project }\end{array}$ & $\begin{array}{l}\text {-Local biogas expert } \\
\text {-Local hire }\end{array}$ & $\begin{array}{l}\text {-Technical literature } \\
\text {-Observe foreign company's } \\
\text { project }\end{array}$ \\
\hline & Delta & $\begin{array}{l}\text {-Founders' experience } \\
\text {-Pilot testing } \\
\text {-Trial-and-error }\end{array}$ & -Local res. collab. & $\begin{array}{l}\text {-Observe foreign company's } \\
\text { project }\end{array}$ \\
\hline & Zeta & $\begin{array}{l}\text {-Project-to-project } \\
\text {-Pilot testing } \\
\text {-In-house lab-testing } \\
\text {-Analysing operational data }\end{array}$ & $\begin{array}{l}\text {-Local eng./constr. company } \\
\text {-User feedback }\end{array}$ & $\begin{array}{l}\text {-Foreign biogas system } \\
\text { designer }\end{array}$ \\
\hline \multirow[t]{7}{*}{$\begin{array}{l}\text { Intermediate } \\
\text { innovative }\end{array}$} & Alpha & $\begin{array}{l}\text {-Project-to-project } \\
\text {-Trial-and-error } \\
\text {-Pilot testing }\end{array}$ & -Local res. collab. & $\begin{array}{l}\text {-Foreign component supplier } \\
\text {-Int. res. col. }\end{array}$ \\
\hline & Beta & -Project-to-project & & $\begin{array}{l}\text {-Foreign component supplier } \\
\text {-Foreign eng./constr. } \\
\text { company }\end{array}$ \\
\hline & Gamma & -Project-to-project & $\begin{array}{l}\text {-Local hire } \\
\text {-Local res. collab. }\end{array}$ & -Technical literature \\
\hline & Delta & -Pilot testing & & \\
\hline & Epsilon & $\begin{array}{l}\text {-Project-to-project } \\
\text {-Project operation } \\
\text {-Analysing operational data }\end{array}$ & & $\begin{array}{l}\text {-Foreign biogas system } \\
\text { designer }\end{array}$ \\
\hline & Zeta & $\begin{array}{l}\text {-Project-to-project } \\
\text {-Analysing operational data }\end{array}$ & $\begin{array}{l}\text {-Local eng./constr. company } \\
\text {-Local res. collab. } \\
\text {-User feedback }\end{array}$ & $\begin{array}{l}\text {-Foreign eng./constr. } \\
\text { company }\end{array}$ \\
\hline & Eta & $\begin{array}{l}\text {-Project-to-project } \\
\text {-Project operation } \\
\text {-Analysing operational data }\end{array}$ & & $\begin{array}{l}\text {-Foreign biogas system } \\
\text { designer }\end{array}$ \\
\hline \multirow[t]{3}{*}{$\begin{array}{l}\text { Advanced } \\
\text { innovative }\end{array}$} & Epsilon & $\begin{array}{l}\text {-Project-to-project } \\
\text {-Project operation } \\
\text {-Analysing operational data } \\
\text {-Pilot testing } \\
\text {-In-house lab-testing }\end{array}$ & $\begin{array}{l}\text {-Acquiring local company's } \\
\text { project }\end{array}$ & $\begin{array}{l}\text {-Foreign hire } \\
\text {-Foreign component supplier } \\
\text {-Foreign biogas system } \\
\text { designer } \\
\text {-Acquiring foreign } \\
\text { company's project }\end{array}$ \\
\hline & Zeta & $\begin{array}{l}\text {-Project-to-project } \\
\text {-Pilot testing } \\
\text {-Analysing operational data }\end{array}$ & $\begin{array}{l}\text {-Local eng./constrs. } \\
\text { company } \\
\text {-Local res. collab. } \\
\text {-User feedback }\end{array}$ & $\begin{array}{l}\text {-Int. res. collab. } \\
\text {-Foreign component supplier } \\
\text {-Foreign biogas system } \\
\text { designer }\end{array}$ \\
\hline & Theta & $\begin{array}{l}\text {-Founders' experience } \\
\text { - In-house lab-testing }\end{array}$ & $\begin{array}{l}\text {-Local hire } \\
\text {-Observe local company's } \\
\text { project }\end{array}$ & $\begin{array}{l}\text {-Foreign component supplier } \\
\text {-Int. res. collab. } \\
\text {-Technical literature } \\
\text {-Observe foreign company's } \\
\text { project }\end{array}$ \\
\hline $\begin{array}{l}\text { World- } \\
\text { leading } \\
\text { innovative }\end{array}$ & Iota & $\begin{array}{l}\text {-Founders' experience } \\
\text {-On-site testing }\end{array}$ & -Local eng./constr. company & $\begin{array}{l}\text {-Foreign hire } \\
\text {-Int. res. collab. } \\
\text {-Foreign component supplier }\end{array}$ \\
\hline
\end{tabular}

Table 9. Learning mechanisms observed at different stages of technological-capability development.

The advanced innovative group includes three firms: Epsilon, Zeta, and Theta. Like the firms in the intermediate innovative class of capabilities, they actively collected and analysed 
performance data and occasionally developed pilot-scale plants to test new substrate types and/or substantial changes in system designs. Epsilon and Theta performed in-house testing, which is rare at lower levels of capability development. The firms included here also made use of some external-domestic learning mechanisms, including productivity-driven learning mechanisms, human resource-based learning, and, in one case, innovation-driven research collaboration. The advanced innovative level is characterised by an even stronger focus on learning from external-foreign sources of knowledge than the firms at the intermediate innovative capability level. This mostly includes project-based learning, but also two cases of international research collaborations (Zeta and Theta). Delta also emphasised that it benefitted from hiring foreign experts into the firm.

Iota is the only firm analysed in this study that exhibits capabilities at the world-leading innovative level. It has maintained this level throughout the entire study period. With respect to learning mechanisms, one of the defining features that sets Iota apart from the other firms is its close partnership with a world-leading research team based in Europe. It has regularly collaborated with this team to work on new-to-the-country and sometimes new-to-the-world innovations. This sometimes also involves the incorporation of new system components sourced from foreign component suppliers. Experimentation with these components has often taken place on full-scale, commercial projects. Furthermore, Iota employs a number of internationally renowned biogas experts and has continuously upgraded its pool of human resources by hiring local and foreign staff. As noted previously, Iota also collaborated with a local engineering and construction company that provided it with market access and detailed knowledge about substrate characteristics.

\section{Discussion}

Our comparative case study of nine biogas-engineering firms in Thailand suggests that there are changes in the kinds of learning mechanisms in which firms engage at different stages on the capability trajectory. Before discussing what these are, we point out some more general insights that stem from our analysis.

To begin with, our data indicate that experience-based learning - e.g., through project-toproject learning or the experience of core staff members - is important at virtually all stages of capability development. This likely stems from the nature of biogas systems, which require substantial adaptation to local project contexts (see Section 3). As a result, the precise impacts of changes in designs often only become evident in the operational phases of projects. This finding has implications for the generalisability of our results, as latecomer learning in industries with substantially different characteristics, such as consumer-product manufacturing, likely involves different learning dynamics (Schmidt and Huenteler, 2016). Thus, the results presented in the present paper are most relevant for latecomer firms in project-based industries (see also Kiamehr, 2017).

Our results also suggest that firms which rely on firm-internal learning mechanisms alone exhibit only low capability levels. In particular, this is evident in the case of Epsilon in the early stages of its lifetime, during which it exhibited capabilities at the basic routine level. Detailed case studies of latecomer capabilities report similar findings (Hansen and Lema, 2019; Hansen and Ockwell, 2014). More generally, this result echoes the key message of the system of innovation approach, namely that linkages and knowledge flows among firms and other organisations are key to innovation processes (Lundvall, 1992; Nelson, 1993). This is perhaps especially relevant for small and medium-sized latecomer firms, which often lack the resources to engage independently in technological search and therefore stand to benefit from learning from external sources of knowledge (e.g., Caniels and Romijn, 2004: 142-3). 
Another general finding of our analysis is that latecomers do not seem to build their capability stocks by relying on any single type of learning mechanism. Instead, they tend to engage in complex and interrelated sets of learning mechanisms. This includes combinations of mechanisms that draw on different sources of knowledge (firm-internal, external-domestic, and external-foreign) and that involve different kinds of activities (productivity-driven, innovation-driven, human-resource-related). While this general finding applies to all our case-study firms, it is particularly evident in the experiences of those that have achieved substantial improvements in their capability stocks (Group II). The finding that learning occurs through engagement in sets of learning mechanisms is in line with the evidence on latecomer capability building reported by Figueiredo et al. (2013) and Hansen and Lema (2019). More generally, this finding highlights the importance of the firm's ability to combine different internal and external resources to take advantage of technological opportunities (Kogut and Zander, 1992; Mathews and Cho, 1999).

We now turn to our more detailed findings regarding changes in learning mechanisms as firms deepen their capability stocks. A key finding in this regard is that the relative frequency of external learning mechanisms seems to change from external-domestic to external-foreign sources of knowledge as firms deepen their capability stocks. However, the absolute frequency of external-domestic learning remains approximately the same across the entire capability spectrum. Additionally, our results indicate that, at low levels of capability development, some of our case-study firms have also engaged in learning based on foreign sources of knowledge. In this sense, our findings differ from previous micro-level investigations of latecomer learning, which argue that external-domestic learning is most relevant for lower-level capabilities and is eventually replaced by external-foreign sources of learning at higher levels (Hansen and Ockwell, 2014; Plechero, 2012). While our results support the idea that there is shift in the relative importance of domestic vs. foreign sources of learning as firms climb the capability ladder, our comparative, micro-level analysis offers a more nuanced picture in this regard. This raises the question of whether domestic and foreign sources of learning should be viewed as substitutes or complements as firms deepen their capability stocks. In our study, foreign and domestic sources of learning seem to be complementary, which might be related to our previous observation regarding the need to adapt biogas systems to the particularities of projects.

Our analysis also provides some insights with respect to changes within categories of learning mechanisms based on different sources of knowledge. A first insight here is that firm-internal learning efforts appear to be important across all capability levels. However, there seems to be a shift in the most relevant types of internal learning mechanisms as one moves up the capability ladder, from learning that predominantly takes place as part of commercial projects at lower levels to more R\&D-based learning at the top. This corresponds with findings by Hansen and Lema (2019) and likely has to do with the accumulation of experience by firm personnel, allowing them to engage creatively with increasingly novel and complex technologies. An additional, related reason for the importance of firm-internal learning across the capability spectrum might be that they are a necessary complement to learning based on external sources of knowledge. Some of these internal learning mechanisms might serve to convert knowledge accessed from external sources. While knowledge conversion, as opposed to knowledge acquisition, has not been discussed in much detail in the present study, we acknowledge that it is key to the diffusion of knowledge within an organisation (Figueiredo, 2003; Kim, 1997; Nonaka, 1994). As the knowledge-intensity of interactions with external organisations increases, there appears to be a need to engage simultaneously in more extensive firm-internal learning efforts to adopt and adapt new knowledge. 
We also observe pronounced changes in the external-foreign category of learning mechanisms along the capability ladder. At lower-level capabilities, foreign learning mechanisms appear to be relatively less important. However, this is not to say that they are irrelevant. In fact, many of our case-study firms reported that they have benefitted from accessing tried-and-tested biogas-system designs from foreign technology suppliers. As firms move towards higher-level capabilities, the frequency of learning based on foreign sources of knowledge increases. As with firm-internal learning mechanisms, there appears to be a shift from mostly commercially focused (and some human resource-related) learning activities to innovation-driven learning. Additionally, the overall diversity of foreign learning mechanisms increases as firms move up the capability ladder. Thus, at a general level, our analysis supports the notion that foreign sources of knowledge become increasingly important at higher stages of capability development (Hansen and Ockwell, 2014; Kim, 1997; Plechero, 2012). However, our comparative, firm-level analysis provides richer insights in this regard, highlighting specifically which types and combinations of foreign-based learning mechanisms are relevant at different stages along the capability trajectory.

There do not seem to be any marked changes in the ways in which our case-study firms engage in external-domestic learning mechanisms along the capability trajectory. With the exception of the basic routine level of capabilities, the frequency with which firms make use of these types of learning mechanisms is approximately the same across all capability levels. While our data suggest that R\&D-based partnerships increase in importance when firms transition from the basic to the intermediate innovative capability level, there are also a range of learning mechanisms that appear to be equally important across nearly all levels of capability development. The importance of learning based on domestic sources likely stems from the need to adapt biogas systems, which again highlights the importance of experience accumulation in the local context. To our knowledge, the continued importance of local/domestic sources of learning has not received much attention in the literature providing micro-level evidence on the subject of latecomer capability building (Figueiredo, 2017; Hansen and Lema, 2019; Hansen and Ockwell, 2014; Kiamehr, 2017).

\section{Conclusion}

The present study provides insights into the localisation of clean-tech industries in the Global South by studying firm-level technological capability building processes. We address the question of how the learning mechanisms that firms engage in change as they accumulate increasingly deeper capability stocks. The research is based on a systematic study of nine technology-supplying firms in the Thai biogas industry over the course of about twenty years. Our results suggest that there are indeed shifts in the relative importance of different types of learning mechanisms as firms develop their capabilities. We find that such shifts tend to follow a co-evolutionary pattern involving shifts within and across learning mechanisms that involve different sources of knowledge.

These insights can provide a basis for decision-makers in government and donor agencies to design targeted interventions to support the growth of green industrial activities in low and middle-income countries. For example, our analysis suggests that, at the low levels of capability development, firms benefit most by obtaining access to high-quality technologies and by developing the resources necessary to absorb them effectively. This can be achieved through the support consultancy services that help latecomers identify suitable technologies, facilitate learning across projects, attract and retain talent, etc. (Cirera and Maloney, 2017). Additionally, based on the observation that capability building in project-based industries like biogas often involves experience-based learning, firms at low levels of capability development might benefit from the promotion of tenders involving multiple projects to be 
developed over extended periods of time (see Kiamehr et al. (2015: 1250) for a similar suggestion).

Firms at intermediate levels of capability development might benefit most from other kinds of policy support. Given that transitions to higher-level innovative capabilities often involve some kind of knowledge input from foreign sources, services in technology transfer could aim to make such knowledge more accessible (Cirera and Maloney, 2017; Mathews and $\mathrm{Hu}$, 2007). Since biogas systems and comparable kinds of technology typically require adaptation to project contexts, such services could usefully be provided by local technology centres or public research institutes that have detailed knowledge of local circumstances. Furthermore, governments could support intermediate-level innovative firms through the promotion of public procurement programmes focused on innovative projects (Edquist et al., 2015). The award of such benefits could be tied to specific requirements, for example, the involvement of foreign project partners, such as component suppliers or specialised consultants.

Governments can also offer support to cultivate and retain firms that possess high levels of capabilities. For instance, in order to incentivise firms to invest more in local R\&D, they could provide some redress for the associated externalities (Cirera and Maloney, 2017; Jaffe et al., 2005). This could take the form of tax incentives or direct grants for innovative projects that address the particular challenges faced by these firms. To develop a local base for the supply of key inputs, the award of such public support measures could be tied to the involvement of local partners (e.g., component suppliers or construction services). Additionally, governments could assist advanced firms to export their products and services by, for example, providing detailed information about relevant foreign markets.

Our study has certain limitations that could usefully be addressed by future research. As highlighted previously, our data on the most relevant learning mechanisms for some of the technological capability levels are limited to observations from only a single firm. Future research could address this by studying larger numbers of firms, for example, by means of a survey-based approach. Also, future investigations on concurrent changes in capability stocks and learning activities could pay more attention to the impacts of other variables, e.g., at the level of the firm (age, size, ownership, etc.), country (industrial structures, labour markets, regulation, etc.), and globally (international value chains, geographical distance, etc.). While we acknowledge the importance of these factors (Figure 1, Section 2.1), in the present analysis we have focused on the micro-level relationship between capability building and learning. 


\section{Appendices}

Appendix A. Additional information about the interviews

\begin{tabular}{|c|c|c|c|c|c|}
\hline Firm & $\begin{array}{l}\text { Number of } \\
\text { interviewees }\end{array}$ & $\begin{array}{l}\text { Interviewee } \\
\text { role(s) }\end{array}$ & Date & Location & Duration \\
\hline Alpha & 1 & $\begin{array}{l}\text { Leading } \\
\text { management } \\
\text { personnel }\end{array}$ & June 2017 & Bangkok & $54 \mathrm{~min}$ \\
\hline Beta & 1 & $\begin{array}{l}\text { Leading } \\
\text { technical } \\
\text { personnel }\end{array}$ & July 2017 & Bangkok & $60 \mathrm{~min}$ \\
\hline Gamma & 2 & $\begin{array}{l}\text { Leading } \\
\text { technical } \\
\text { personnel }\end{array}$ & $\begin{array}{l}\text { August } \\
2017\end{array}$ & Bangkok & $56 \mathrm{~min}$ \\
\hline Delta & 1 & $\begin{array}{l}\text { Leading } \\
\text { management } \\
\text { personnel }\end{array}$ & July 2017 & Bangkok & $52 \min$ \\
\hline Epsilon & 1 & $\begin{array}{l}\text { Leading } \\
\text { management } \\
\text { personnel }\end{array}$ & July 2017 & Bangkok & $68 \mathrm{~min}$ \\
\hline Zeta & 2 & $\begin{array}{l}\text { Leading } \\
\text { management } \\
\text { and technical } \\
\text { personnel }\end{array}$ & July 2017 & Chiang Mai & $64 \mathrm{~min}$ \\
\hline Eta & 2 & $\begin{array}{l}\text { Leading } \\
\text { management } \\
\text { and technical } \\
\text { personnel }\end{array}$ & July 2017 & Bangkok & $52 \mathrm{~min}$ \\
\hline Theta & 2 & $\begin{array}{l}\text { Leading } \\
\text { management } \\
\text { and technical } \\
\text { personnel }\end{array}$ & July 2017 & Bangkok & $118 \mathrm{~min}$ \\
\hline Iota & 1 & $\begin{array}{l}\text { Leading } \\
\text { management } \\
\text { personnel }\end{array}$ & July 2017 & Bangkok & $53 \mathrm{~min}$ \\
\hline
\end{tabular}

Table A.1: Additional information about interviews.

Appendix B. Interview protocol

\section{General information about the firm}

\section{Historical background}

- When was your firm founded?

- How was the company established? Please explain the ownership structure of the firm at the time of its foundation. Has this changed? How?

- Who are the founders of the firm? What are their backgrounds?

- Please describe the different units within the company and their functions. Have any units become added or terminated during the lifetime of the firm?

- How many people were employed when the firm was founded? How many are working there now? Please distinguish between numbers of workers in the firms' different units.

- Please explain your role in the company? Has this changed? How?

Business profile 
- What is the strategic orientation or mission statement of the firm? Has this changed? How?

- What products and services does your firm offer? Has this changed? How?

- What is the main product or service that your firm offers?

- Which countries constitute your firm's main markets? Has this changed? How?

- Approximately, in how many anaerobic digestion reactor projects has your company been involved?

\section{Identification of technological milestones}

At the beginning of this section, the interviewee(s) was (were) introduced to some examples that constitute technological milestones and breakthroughs. The examples mentioned include: generation of new knowledge about the anaerobic digestion process, the development of intellectual property, landmark projects, the development of new plant designs, substantial modifications to existing plant designs, and the achievement of significant cost or performance improvements of plants. In addition, the interviewee(s) was (were) informed that the milestones should demonstrate the firm's increased level of knowledge, experience, and skill to understand, handle, and improve anaerobic digestion reactors, reactor components, and supporting systems.

- Could you please name and briefly describe between 4 and 6 of the major technological milestones that your firm has achieved since its foundation?

\section{Details of each individual milestone}

\section{Revealed technological capabilities}

- Could you please tell us about the concrete outcomes that this milestone has involved?

- How would you rate the milestone with regards to its technological originality at the time that it was developed? Was it new to the firm, new to a particular market segment, new to Thailand, or new to the world?

- What performance measures and indicators has your firm used to evaluate the success of the milestone?

- What strategic goals did your company pursue when working on this milestone?

- Questions about resources:

- Did the milestone involve any major financial commitments?

- Approximately how many employees were involved?

- Which firm units were involved?

- Was there any substantial coordination across firm units?

- Please explain the time horizon of the project.

- Approximately when did your company start to work on tasks related to the achievement of the milestone?

○ When did the work finish?

- Could you please describe the specific methods and tools that your company has used to achieve this technological milestone? Please provide as much detail as you can.

- What qualifications did the key personnel involved in the achievement of this milestone have?

Learning mechanisms 
- Internal learning mechanisms

○ Which types of firm-internal learning mechanisms did your firm use to address the specific challenges related to this particular milestone?

$\circ$ When exactly were these used? Were the learning mechanisms pursued continuously over long periods of time or rather as one-off events?

- External learning mechanisms

- What kinds of external learning sources were used?

$\circ$ When exactly were these used? Were these learning mechanisms pursued continuously over long periods of time or rather as one-off events?

- What kinds of organisations were involved in these learning experiences? Were these Thai or foreign organisations? Please provide their names if you can.

- What exactly was the nature of the relationships between your firm and the external organisations?

- Importance of different learning mechanisms

○ Which of the mentioned learning mechanisms (internal or external) would you say were most important for achieving this milestone?

- Please elaborate on the extent to which the different learning sources were prioritised and actively pursued by firm management (in terms of financial commitments, human resources allocated, etc.).

○ Were specific learning processes combined? If so, how?

Appendix C. Supplementary information

See attached file labelled "RH 2020 Supplementary information.xlsx"

\section{Funding}

This work was supported through a Ph.D. scholarship awarded by the United Kingdom Engineering and Physical Research Council.

\section{Acknowledgements}

The lead author would like to thank his Ph.D. supervisors, Ilkka Keppo and Will McDowall. He would also like to thank Kasetsart University's Chaloemphrakiat Sakon Nakhon Province campus for their hospitality during the fieldwork undertaken for this research. In particular, he would to thank Dr Rathanit Sukthanapirat for her assistance in organising some of the interviews that were conducted as part of this study. 


\section{References}

Amsden, A.H., Tschang, F.T., 2003. A new approach to assessing the technological complexity of different categories of R\&D (with examples from Singapore). Res. Policy 32, 553-572. https://doi.org/10.1016/S0048-7333(02)00080-X

Ariffin, N., 2010. Internationalisation of technological innovative capabilities: levels, types and speed (learning rates) in the electronics industry in Malaysia. Technol. Learn. Inno. Dev. 3, 347-391. https://doi.org/10.1504/IJTLID.2010.039164

Ariffin, N., Figueiredo, P.N., 2004. Internationalization of innovative capabilities: counterevidence from the electronics industry in Malaysia and Brazil. Oxf. Dev. Stud. 32, 559-583. https://doi.org/10.1080/1360081042000293344

Bachmann, N., 2013. Design and Engineering of Biogas Plants, in: The Biogas Handbook: Science, Production, and Applications. Woodhead Publishing, Oxford.

Bell, M., 1984. Learning and the Accumulation of Technological Capabilities, in: Fransman, K.K. (Eds.), Technological Capability in the Third World. Macmillan, London. https://doi.org/10.1007/978-1-349-17487-4_10

Bell, M., Figueiredo, P.N., 2012. Building innovative capabilities in latecomer emerging market firms: some key issues, in: Amann, E., Cantwell, J. (Eds.), Innovative Firms in Emerging Market Countries. Oxford University Press, pp. 24-138. https://doi.org/10.1093/acprof:oso/9780199646005.001.0001

Bell, M., Pavitt, K., 1995. The development of technological capabilities, in: Trade, Technology, and International Competitiveness. The World Bank, Washington, D.C, pp. 69-101.

Caniels, M.C.J., Romijn, H., 2004. Technological learning in small-enterprise clusters: conceptual framework and policy implications, in: Mani, S., Romijn, H. (Eds.), Innovation, Learning, and Technological Dynamism in Developing Countries. United Nations University Press, Paris, pp. 135-157.

Chen, L.-C., 2009. Learning through informal local and global linkages: the case of Taiwan's machine tool industry. Res. Policy 38, 527-535.

https://doi.org/10.1016/j.respol.2008.10.008

Cirera, X., Maloney, W.F., 2017. The innovation paradox: developing-country capabilities and the unrealized promise of technological catch-up. World Bank Group, Washington, D.C. https://doi.org/10.1596/978-1-4648-1160-9

Cohen, W.M., Levinthal, D.A., 1990. Absorptive capacity: a new perspective on learning and innovation. Adm. Sci. Q. 35, 128. https://doi.org/10.2307/2393553

Dahlman, C.J., Ross-Larson, B., Westphal, L.E., 1987. Managing technological development: lessons from the Newly Industrializing Countries. World Dev. 15, 759-775. https://doi.org/10.1016/0305-750X(87)90058-1

Dantas, E., Bell, M., 2011. The co-evolution of firm-centered knowledge networks and capabilities in late industrializing countries: the case of Petrobras in the offshore oil innovation system in Brazil. World Dev. 39, 1570-1591. https://doi.org/10.1016/j.worlddev.2011.02.002

Dutrénit, G., 1998. From knowledge accumulation to strategic capabilities: knowledge management in a Mexican glass firm (doctoral thesis). University of Sussex, Brighton.

Dutrénit, G., Lee, Lee, K., Nelson, R., Soete, L., Vera-Cruz, A.O., 2013. Learning, Capability Building, and Innovation for Development. Palgrave Macmillan, New York.

Edquist, C., Vonortas, N.S., Zabala-Iturriagagoitia, J.M., Edler, J., 2015. Public Procurement for Innovation. Edward Elgar Publishing, Cheltenham, UK. https://doi.org/10.4337/9781849809740.00025 
Eisenhardt, K.M., Graebner, M.E., 2007. Theory building from cases: opportunities and challenges. Acad Manage J 50, 25-32. https://doi.org/10.5465/amj.2007.24160888

Energy Policy Planning Office, 2016. EPPO Journal Special Issue 2016. https://issuu.com/eppojournal/docs/eppo_journal_special_issue_2016 (accessed 27 April 2020).

Energy Research and Development Institute Nakornping, Chiang Mai University, 2017. How Thailand achieved explosive growth in its biogas sector through policy development and industry support.

Ernst, D., Mytelka, L., Ganiatsos, T., 1998. Technological capabilities in the context of export-led growth: a conceptual framework, in: Ernst, D., Mytelka, L. (Eds.), Technological Capabilities and Export Success in Asia. Routledge, London, pp. 545.

Figueiredo, P.N., 2017. Micro-level technological capability accumulation in developing economies: insights from the Brazilian sugarcane ethanol industry. J. Clean. Prod. 167, 416-431. https://doi.org/10.1016/j.jclepro.2017.08.201

Figueiredo, P.N., 2003. Learning, capability accumulation and firms' differences: evidence from latecomer steel. Ind. Corp. Change 12, 607-643. https://doi.org/10.1093/icc/12.3.607

Figueiredo, P.N., Cohen, M., Gomes, S., 2013. Firms' innovation capability-building paths and the nature of changes in learning mechanisms: multiple case-study evidence from an emerging economy. UNU-MERIT Working Paper Series \#2013-007.

Hansen, U.E. Larsen, T.H., Bhasin, S., Burgers, R., Larsen, H., 2020. Innovation capability building in subsidiaries of multinational companies in emerging economies: insights from the wind turbine industry. J. Clean. Prod. 244, 118746. https://doi.org/10.1016/j.jclepro.2019.118746

Hansen, U.E., Lema, R., 2019. The co-evolution of learning mechanisms and technological capabilities: lessons from energy technologies in emerging economies. Technol. Forecas. Soc. Change 140, 241-257. https://doi.org/10.1016/j.techfore.2018.12.007

Hansen, U.E., Ockwell, D., 2014. Learning and technological capability building in emerging economies: the case of the biomass power equipment industry in Malaysia.

Technovation 34, 617-630. https://doi.org/10.1016/j.technovation.2014.07.003

Hobday, M., Rush, H., 2007. Upgrading the technological capabilities of foreign transnational subsidiaries in developing countries: the case of electronics in Thailand. Res. Policy 36, 1335-1356. https://doi.org/10.1016/j.respol.2007.05.004

International Energy Agency, 2020. Data and statistics. https://www.iea.org/data-andstatistics?country=WORLD\&fuel=Energy\%20supply\&indicator=Total\%20primary\% 20energy\%20supply\%20(TPES)\%20by\%20source (accessed 28 July 2020).

International Organisation for Standardization, 2018. ISO/IEC 17025:2005. https://www.iso.org/standard/39883.html (accessed 27 April 2020).

International Renewable Energy Agency, 2017. Renewable energy outlook Thailand. International Renewable Energy Agency \& Thai Ministry of Energy, Abu Dhabi.

Jaffe, A.B., Newell, R.G., Stavins, R.N., 2005. A tale of two market failures: technology and environmental policy. Ecol. Econ. 54, 164-174. https://doi.org/10.1016/j.ecolecon.2004.12.027

Jonker, M., Romijn, H., Szirmai, A., 2006. Technological effort, technological capabilities and economic performance. Technovation 26, 121-134. https://doi.org/10.1016/j.technovation.2004.10.002

Katz, J.M., 1984. Domestic technological innovations and dynamic comparative advantage. J. Dev. Econ. 16, 13-37. https://doi.org/10.1016/0304-3878(84)90100-7 
Kesidou, E., Romijn, H., 2008. Do local knowledge spillovers matter for development? an empirical study of Uruguay's software cluster. World Dev. 36, 2004-2028. https://doi.org/10.1016/j.worlddev.2008.01.003

Kiamehr, M., 2017. Paths of technological capability building in complex capital goods: the case of hydro electricity generation systems in Iran. Technol. Forecas. Soc. Change 122, 215-230. https://doi.org/10.1016/j.techfore.2016.03.005

Kiamehr, M., Hobday, M., Hamedi, M., 2015. Latecomer firm strategies in complex product systems (CoPS): the case of Iran's thermal electricity generation systems. Res. Policy 44, 1240-1251. https://doi.org/10.1016/j.respol.2015.02.005

Kiamehr, M., Hobday, M., Kermanshah, A., 2014. Latecomer systems' integration capability in complex capital goods: the case of Iran's electricity generation systems. Ind. Corp. Change 23, 689-716. https://doi.org/10.1093/icc/dtt036

Kim, L., 1998. Crisis construction and organizational learning: capability building in catching-up at Hyundai Motor. Organ. Sci. 9, 506-521.

https://doi.org/10.1287/orsc.9.4.506

Kim, L., 1997. Imitation to Innovation: the Dynamics of Korea's Technological Learning. Harvard Business School Press, Boston.

Kogut, B., Zander, U.D.O., 1992. Knowledge of the firm, combinative capabilities, and the replication of technology. Organ. Sci. 3, 383-397. https://doi.org/10.1287/orsc.3.3.383

Lall, S., 1992. Technological capabilities and industrialization. World Dev. 20, 165-186. https://doi.org/10.1016/0305-750X(92)90097-F

Lema, R., Hanlin, R., Hansen, U.E., Nzila, C., 2018. Renewable electrification and local capability formation: linkages and interactive learning. Energy Policy 117, 326-339. https://doi.org/10.1016/j.enpol.2018.02.011

Lema, R., Lema, A., 2012. Technology transfer? The rise of China and India in green technology sectors. Inno. Dev. 23-44. https://doi.org/10.1080/2157930X.2012.667206

Lundvall, B.-A., 1992. National Systems of Innovation: Toward a Theory of Innovation and Interactive Learning. Anthem Press, London.

Luo, S., Lovely, M.E., Popp, D., 2013. Intellectual returnees as drivers of indigenous innovation: evidence from the Chinese photovoltaic industry. National Bureau of Economic Research. https://doi.org/10.1111/twec.12536

Malerba, F., 1992. Learning by firms and incremental technical change. Econ. J. 102, 845. https://doi.org/10.2307/2234581

Mathews, J.A., Hu, M.-C., 2007. Enhancing the role of universities in building national innovative capacity in Asia: the case of Taiwan. World Dev. 35, 1005-1020. https://doi.org/10.1016/j.worlddev.2006.05.012

Mathews, J.A., Cho, D.-S., 1999. Combinative capabilities and organizational learning in latecomer firms: the case of the Korean semiconductor industry. J. World Bus. 34, 139-156. https://doi.org/10.1016/S1090-9516(99)00013-9

Mehner, M., Tuttaworn, C., Srisutam, P., Khusribanchong, N., 2017. Thailand Biogas: Zielmarktanalyse 2017 mit Profilen der Marktakteure. German-Thai Chamber of Commerce, Bangkok.

Mendonça, S., Pereira, T.S., Godinho, M.M., 2004. Trademarks as an indicator of innovation and industrial change. Res. Policy 33, 1385-1404. https://doi.org/10.1016/j.respol.2004.09.005

Nelson, R., 1993. National Innovation Systems: a Comparative Analysis. Oxford University Press, New York. 
Nonaka, I., 1994. A dynamic theory of organizational knowledge creation. Organ. Sci. 5, 14 37. https://doi.org/10.1287/orsc.5.1.14

Ockwell, D., Sagar, A., de Coninck, H., 2015. Collaborative research and development (R\&D) for climate technology transfer and uptake in developing countries: towards a needs driven approach. Clim. Change 131, 401-415. https://doi.org/10.1007/s10584014-1123-2

OECD, 2005. Oslo Manual: guidelines for collecting and interpreting innovation data, 3rd ed. Organisation for Economic Co-operation and Development: Statistical Office of the European Communities, Paris.

Peltoniemi, M., 2011. Reviewing industry life-cycle theory: avenues for future research. Int. J. Manag. Rev. 13, 349-375. https://doi.org/10.1111/j.1468-2370.2010.00295.x

Plechero, M., 2012. The changing geography of innovation: Chinese and Indian regions and the global flows of innovation (doctoral thesis). Lund University, Lund.

Quitzow, R., Huenteler, J., Asmussen, H., 2017. Development trajectories in China's wind and solar energy industries: how technology-related differences shape the dynamics of industry localisation and catching-up. J. Clean. Prod.158, 122-133. https://doi.org/10.1016/j.jclepro.2017.04.130

Radosevic, S., Yoruk, E., 2018. Technology upgrading of middle income economies: a new approach and results. Technol. Forecas. Soc. Change 129, 56-75. https://doi.org/10.1016/j.techfore.2017.12.002

Radosevic, S., Yoruk, E., 2016. Why do we need a theory and metrics of technology upgrading? Asian J. Technol. Innov. 24, 8-32. https://doi.org/10.1080/19761597.2016.1207415

Rahayu, A.S., Karsiwulan, D., Yuwono, H., Trisnawati, I., Mulyasari, S., Rahardjo, S., Hokermin, S., Paramita, V., 2015. Handbook: POME-to-biogas project development in Indonesia. Winrock International.

Reinauer, T., 2019. Learning among latecomer firms in low-carbon energy technology: the case of the Thai biogas industry (doctoral thesis). University College London, London.

Romijn, H., 1999. Acquisition of Technological Capability in Small Firms in Developing Countries. Macmillan, London.

Seawright, J., Gerring, J. 2008. Case selection techniques in case study research. Political Res. Q. 61, 294-308. https://doi.org/10.1177/1065912907313077

Schmidt, T.S., Huenteler, J., 2016. Anticipating industry localization effects of clean technology deployment policies in developing countries. Glob. Environ. Change 38, 8-20. https://doi.org/10.1016/j.gloenvcha.2016.02.005

Scott-Kemmis, D., Chitravas, C., 2007. Revisiting the learning and capability concepts: building learning systems in Thai auto component firms. Asian J. Technol. Innov. 15, 67-100. https://doi.org/10.1080/19761597.2007.9668638

Siteur, J., 2012. Rapid deployment of industrial biogas in Thailand: factors of success. Institute for Industrial Productivity, Washington, D.C.

Suwansari, K., Trakulvichean, S., Grudloyma, U., Songkasiri, W., Commins, T., Chaiprasert, P., Tanticharoen, M., 2015. Biogas: key success factors for promotion in Thailand. J. Sustain. Energy Environ. 25-30.

Tacla, C.L., Figueiredo, P.N., 2006. The dynamics of technological learning inside the latecomer firm: evidence from the capital goods industry in Brazil. Int. J. Technol. Manag. 36, 62. https://doi.org/10.1504/IJTM.2006.009962

Tsekouras, G., 2006. Gaining competitive advantage through knowledge integration in a European industrialising economy. Int. J. Technol. Manag. 36, 126. https://doi.org/10.1504/IJTM.2006.009965 
UNFCCC, 2014. Executive Board Annual Report 2014: Clean Development Mechanism. https://unfccc.int/resource/docs/publications/unfccc_cdm-eb_annual_report2014.pdf (accessed 27 April 2020).

UNFCCC, 1998. Kyoto Protocol to the United Nations Framework Convention on Climate Change. https://unfccc.int/resource/docs/convkp/kpeng.pdf (accessed 27 April 2020).

Van Dijk, M., Bell, M., 2007. Rapid growth with limited learning: industrial policy and Indonesia's pulp and paper industry. Oxf. Dev. Stud. 35, 149-169. https://doi.org/10.1080/13600810701322017

Vannoni, M., 2015. What are case studies good for? Nesting comparative case study research into the Lakatosian research program. Cross Cult. Res. 49, 331-357. https://doi.org/10.1177/1069397114555844

World Bioenergy Association, 2017. WBA global bioenergy statistics 2017. https://worldbioenergy.org/uploads/WBA\%20GBS\%202017_hq.pdf (accessed 27 April 2020).

Yin, R.K., 2003. Case study research: design and methods, 3rd ed. Sage, Thousand Oaks. 


\section{Highlights}

- Structured micro-level study of technological capability building at nine firms

- Sheds light on heterogeneity in capability trajectories and learning activities

- Highlights changes within and across sources of learning as capability stocks grow

- Discusses policy support mechanisms for firms at different stages of development 


\section{Declaration of interests}

$\bigotimes$ The authors declare that they have no known competing financial interests or personal relationships that could have appeared to influence the work reported in this paper.

$\square$ The authors declare the following financial interests/personal relationships which may be considered as potential competing interests: 